\title{
Progress and Poverty \\ in Early Modern Europe
}

By

\author{
Robert C. Allen \\ Nuffield College \\ New Road \\ Oxford OX1 1NF
}

Email: bob.allen@nuffield.oxford.ac.uk

2004 
At the end of the middle ages, the urban, manufacturing core of Europe was on the Mediterranean with an important offshoot in Flanders. The Netherlands was thinly populated, ${ }^{1}$ and England was an agrarian periphery. By 1800, the situation was largely reversed. First, the Netherlands and, then, Britain emerged as commercial and manufacturing powerhouses with the largest urban economies in Europe. Italy and Spain slipped behind. Only present-day Belgium managed to remained near the leaders, perhaps because of proximity to the Netherlands.

Explaining this reversal in fortunes has been a central problem of social science, and the literature includes many conflicting hypotheses. This paper attempts to give an integrated assessment of six, in particular:

\section{1. population}

Population can function in two ways to explain social and economic change in early modern Europe. First, changes in the land-labour ratio can explain changes in real wages and land rents. These changes, in turn, may affect other aspects of economic life like the extent of serfdom or proto-industrialization. Second, different demographic regimes may affect development by changing population growth and income levels. Hajnal (1965) has identified differences in marriage patterns that suggest that western Europe exhibited Malthus' preventive check, while eastern Europe may have been an example of the positive check model. Historians of the 'European Miracle' have argued that just such a difference accounts for Europe's lead over Asia (Jones 1981, Blaut 1993, pp. 128-35). Perhaps, it accounts for the advance of northwestern Europe as well (Weir 1984)?

\section{2. enclosure}

Modernization of traditional rural society is a long standing explanation of northwestern Europe's lead. The English enclosure movement is the inspiration for this theory. Liberals have emphasized that enclosure replaced communal property with private property, which they regard as more 'efficient' since it more tightly aligned the interests of farmers and landlords with the results of their decisions (North and Thomas 1973, Hardin 1998). Marxists have emphasized that the three tiered social structure--landlords, tenant farmers, and landless labourers--that emerged in the eighteenth century and that seemed to accompany enclosure was a 'capitalist' arrangement that forced farmers to innovate since high productivity was the only way to pay their landlords and their workers. ${ }^{2}$

\section{3. empire}

The English and the Dutch were both winners in the early modern scramble for Empire, and that success is the inspiration for the Imperial theory of economic development. Marx developed this theme as well as the agrarian argument. The role of empire as a source of capital and a market for manufactures has since been emphasized by 'world system theorists' like Wallerstein (1974-91), Arrighi (1994), and Frank (1974, 1998). Acemoglu, Johnson and Robinson (2002) also emphasize the importance of Asian and American trade..

${ }^{1}$ Van Zanden (2002) has argued that the Netherlands was already advanced in 1500, and that view is supported by its relatively high agricultural productivity and urbanization (Table 1 , Figures 2, 6-8).

\footnotetext{
${ }^{2}$ See Brenner (1976), for instance, and the spirited debate in Aston and Philpin (1985).
} 
4. representative government

Eighteenth century liberals contrasted the absolutism of France with England's "mixed monarchy" and the constitution of the Dutch Republic. Representative institutions were alleged to be economically superior, as evidenced by lower interest rates in England and the Netherlands compared to France. These arguments have been restated by recent theorists like North and Weingast (1989) and De Long and Schleifer (1993), who allege that absolutist kings expropriated property and raised taxes in ways that discouraged business enterprise.

\section{5. technology}

Theorists have long emphasized that continuous technological progress is the only basis for sustained economic growth (e.g. Jones 1998). The relationship between the scientific revolution of the seventeenth century and the industrial revolution has been long discussed, and their relationship has been recently probed by Jacob (1997) and Mokyr (2002), who argue that northwestern Europe benefitted from an 'industrial enlightenment' (in Mokyr's phrase) and England, in particular, benefitted from a distinctive scientific culture that led to economic advance. But can we measure technological performance and assess its contribution to economic growth?

\section{6. literacy}

A final candidate to explain success was the spread of literacy. When Gutenburg invented moveable type in the mid-fifteenth century, less than $10 \%$ of adult Europeans could sign their names. By 1800, the proportion was higher everywhere, and it exceeded half in the economic leaders. Much recent theorizing has emphasized the importance of education and human capital accumulation for economic growth, so it makes sense to probe its importance in earlier years. Was a literate population the seed bed for economic expansion?

The importance of these developments have been extensively debated, usually in terms of internal coherence. The enclosure argument, for instance, has been called into question by historians who have denied that enclosure led to much agricultural productivity growth ${ }^{3}$. The empire argument has been attacked on the grounds that the extra-European markets were too

${ }^{3}$ Comparisons of open and enclosed villages and large and small farms find that the England's peculiar rural institutions made little contribution to productivity (Allen 1992, Clark 1998). Likewise, studies of share cropping in southern Europe and the Mesta in Spain find them to have been more efficient than Liberals and Marxists have thought (Hayami and Otsuka 1993, Hoffman 1996, Nugent and Sanchez 1989, Simpson 1995). International comparisons also call the importance of 'modern' institutions into question: The open field farmers of northeastern France achieved wheat yields that were on a par with those of enclosed farmers in England (O'Brien and Keyer 1978, Allen and O'Grada 1988). And the farmers who accomplished the Dutch agricultural revolution were mainly owner-occupiers rather than the capitalist tenants of great estates (De Vries 1974). 
small to matter as were the profits earned on slavery and colonial trades. ${ }^{4}$ The representative government argument has been disputed by those who assert that France did not have particularly high interest rates or taxes. Recent research has downplayed the importance of technological progress and literacy in explaining the British industrial revolution.

This paper takes a different approach to assessment by estimating a five equation simultaneous equation model of European development. The model explains five variables-the population, the wage rate, urbanization, agricultural productivity, and the proto-industrial revolution. It is estimated with an aggregate data set for Europe from 1300 to 1800. The units of observations are countries at roughly century intervals--e.g. Spain in 1400, Spain in 1500, Poland in 1750, etc. The countries are defined in terms of post-World War II boundaries and include England \& Wales, Belgium, France, the Netherlands, Spain, Italy, Germany, Poland, and Austria/Hungary/Czechoslovakia. The years include 1300, 1400, 1500, 1600, 1700, 1750, and 1800, although observations in 1300 are available only for England and Italy, while the Netherlands does not enter the data set until 1500.

A very serious issue is whether countries are appropriate units of analysis. One question is whether they were homogeneous enough. Was there an 'English' or an 'Italian' wage, for instance? In many respects, the countries were internally heterogeneous, and I represent them with averages. However, if world empires or agrarian institutions were powerful enough to remake societies, their effects should show up in the average experience of the nations concerned. And they do.

A second question is whether the same model fits all countries; in particular, does a single, five equation model summarize the variety of development experiences seen in early modern Europe or do we need specific, different models for each country to capture the divergent paths of development on the continent? The surprising answer is that one model does fit all, and it indicates why some countries were more successful than others.

\section{$\underline{\text { Success and Failure }}$}

We can distinguish the successful from the unsuccessful economies by three indicators-real wages, economic structure, and agricultural productivity. These require discussion since they are the axes around which the present analysis is constructed.

Income is fundamental and is best measured by the real wage. ${ }^{5}$ Figure 1 plots real wages

${ }^{4}$ The debate is enormous. A few relevant works showing the diversity of approaches includes Williams (1994), Wallerstein (1974, 1979), Frank (1978), Findlay (1990), Darity (1992), Engerman (1972, 1998), Thomas and Bean (1974), O'Brien (1982, 1999), O'Brien and Engerman (1991), and O'Brien and Prados de la Escosura (1998). Morgan (2001) is a survey of some important aspects.

${ }^{5}$ Maddison (2001) has estimated GDP per head for many countries in the early modern period. Some of his estimates concur with the usual view of the period. Thus, he shows Italy to have had the highest income in Europe in 1500 and to show little growth from then until 1820. Likewise, the Dutch Republic and the UK show considerable growth between 1500 and 1820 and are the two richest economies then. More problematic reconstructions include Spain, which 
for leading European cities and highlights the differences in performance between regions. In the fifteenth century, wages in northwestern Europe were already higher than elsewhere on the continent, but the advantage was comparatively small. A large gap emerged by 1750 . This was not because of advance in the north but rather because real wages collapsed in central and southern Europe. Figure 1 shows the drop for Valencia and Vienna. Similar declines occurred in other cities in France, Spain, Italy, Germany, Austria, and Poland. Conversely, the real wage in London showed ups and downs, but the trend was stable in the long run. Real wages in Antwerp and Amsterdam likewise showed little trend from 1500 to 1800 (Allen 2001). Roughly speaking, real wages were constant in the leading cities of northwestern Europe between 1500 and 1750, while they were halved elsewhere on the continent.

Concentration on the real wage also links economic success in early modern Europe to one of the great divides of human history-the escape from the Malthusian trap. Europe took its first steps in that direction between 1500 and 1800. Previously, if an economic expansion raised the standard of living of the majority of the population, their good fortune was unsustainable since the better living conditions induced an increase in population that eventually drove the standard of living back to its earlier value (Abel 1980, Le Royal Ladurie 1974, Postan 1950, 1975, Wrigley and Schofield 1981). The economic expansions of the Dutch and English, however, were sustained for centuries without serious falls in the standard of living. This was not because fertility was restrained; on the contrary, these countries had the most rapidly growing populations in Europe. The secret to their success was maintaining even more rapid growth in their economies (North and Thomas 1974). The problem of combining economic growth and stable living standards was solved for the first time by vigorous economic expansion rather than by demographic restraint.

The economies that achieved high wages in 1750 were also the ones that experienced the most rapid structural change. Table 1 shows the distribution of the population in major European countries in 1500 and 1800. At the end of the middle ages, Italy, Spain, and presentday Belgium were the leading economies, and they had the smallest fractions of their populations in agriculture and the largest urban shares. Elsewhere, about three quarters of the population was agricultural--a proportion similar to that in most less developed countries early in the twentieth century--and the urban population was correspondingly small.

It is useful to distinguish four groups in analyzing changes in the early modern period. England was undoubtedly the most successful economy with a drop in the agricultural share of the population to $35 \%$ and a rise in both the urban and "rural nonagricultural" shares. The latter corresponds to the "proto-industrial revolution," which involved the expansion of manufacturing (particularly textiles) in small villages organized in the putting out system (Mendels 1972). Belgium and the Netherlands experience a similar transformation with agriculture dropping to

was a rapidly growing economy in this period, according to Maddison's figures. Discrepancies like this emphasize that GDP estimates for the early modern period must be treated with great caution. Even for the early nineteenth century, the calculation of GDP per head is fraught with difficulties. Thus, Maddison (1995) and Prados de la Escosura (2000) agree that Britain had the highest income in Europe in 1820, but they disagree significantly about the income of the USA. Maddison puts it below Britain's, while Prados puts it above. The differences in ranking reflect difficulties in deflation, for which there are no simple solutions. 
$49 \%$ and $41 \%$ of the population, respectively, in 1800 . Spain and Italy showed little change in economic structure, and, indeed, much of the growth in northwestern Europe was at their expense as key industries like woolen textiles relocated from the south to the north. Finally, France, Germany, Austria, and Poland experienced only modest structural transformation. The small decline in the agricultural share was reflected in rural manufacturing rather than in the growth of cities. While historians of proto-industry have often been enthusiastic about its development potential--hence the term--it was as often associated with economic stagnation as with advance (Coleman 1983).

Agricultural productivity is a third indicator of economic success in the early modern period. An immediate reason why England and the Netherlands could reduce the fractions of their populations in agriculture was because the productivity of farmers and cultivators increased substantially between the middle ages and the nineteenth century. Output per agriculturalist was high in present day Belgium during the middle ages and remained high through 1800. England and the Netherlands were the two countries to have agricultural revolutions in the early modern period: English and Dutch labour productivity was low in the medieval period but closed the gap with Belgium during the seventeenth and eighteenth centuries (Allen 2000). Roughly the same was true of total factor productivity ${ }^{6}$, as shown in Figure 2. Rising agricultural efficiency contributed to economic development by providing food, wool, and flax to support the nonagricultural economy, by releasing labour for manufacturing employment, and by providing a surplus that could finance investment or sustain the conspicuous consumption of the aristocracy and state.

\section{Modeling Progress and Poverty}

In explaining economic development, we must distinguish between the explanatory variables and those that are explained. The model developed here explains five variables-population, the real wage, the urban and proto-industrial shares of the population, and agricultural productivity. They are endogenous variables; each influences the other. A productive agriculture, for instance, promoted large cities, while urbanization induced agricultural productivity growth. The view of development is, thus, one in which living standards, urbanization, proto-industrialization, and agricultural revolutions were mutually reinforcing. Neither was a prime mover pushing all of the others forward. These five variables are all ultimately explained by other variables in the model-the enclosure of the open fields, for instance, and the establishment of world empires. Other prime movers include the literacy rate, a productivity variable indexing the growth of competitive advantage in the new draperies, previous levels of urbanization, the land-labour ratio. The model contains five equations to explain the five endogenous variables-population, the real wage, the urban and proto-industrial shares of the population, and agricultural productivity-in terms of the other variables.

The model works as a recursive system. In each time period (century), four equations are solved to determine four endogenous variables-the real wage, the urban and proto-industrial shares of the population, and agricultural productivity-in terms of the exogenous variables and the population. Figure 3 is a flow diagram that shows the logic of this solution. The diagram

\footnotetext{
${ }^{6}$ The calculation of agricultural TFP is explained in Appendix I.
} 
shows the links between variables that emerge as important in the statistical analyses to be discussed: many more links were examined but failed to be statistically or historically significant. The four endogenous variables are shown in rectangles and the exogenous (explanatory) variables are shown in circles. The endogenous variables influenced each other in many ways. Higher urbanization, for instance, led to higher agricultural productivity. Causation worked in the opposite way as well with higher agricultural productivity increasing the share of the population living in cities. In the model developed here, agricultural and urban revolutions are both a cause and a consequence of economic development.

Population change links successive solutions of the model summarized in Figure 3: once the model is solved for one period, the implied wage and urbanization rates are used to project population forward to the next period. The process is then repeated as the model is resolved to determine the wage, urbanization, agricultural productivity, and proto-industry for the new period. Urbanization was also a self-perpetuating process that links one simulation period to the next.

Figure 3 shows the variables that were ultimately causal, and their influence is what would be expected on general grounds. I review them in turn.

Land-labour ratio

The standard explanation for falling real wages in the sixteenth and seventeenth centuries is population growth in the context of a fixed supply of natural resources (Abel 1980, Le Royal Ladurie 1974, Postan 1950, 1975, Wrigley and Schofield 1981, Wrigley 1988). This diminishing returns effect is confirmed in the present model. Here the natural resource base is measured by agricultural land, $T$, in the 1950s. While there were improvements in the quality of land over the period, the total did not change in most cases. ${ }^{7}$ The labour force, $\mathrm{L}$, is indexed by the population, and I use Bairoch's (1988a, p. 297) estimates, which are generally taken from McEvedy and Jones (1978). ${ }^{8}$ The land and population estimates supposedly apply to post-World

${ }^{7}$ Land is the area of agricultural land as given in the U.N. Food and Agricultural Organization, Production Year-Book, 1958, Vol. 12, p. 3. (Figures for England and Wales are taken from Stamp 1965, p. 30. The corresponding figures for the U.K. agree with the FAO's.) Agricultural land includes cropped land, meadow, pasture, and rough grazing, but not forest. This total is treated as a constant for each country from 1300 to 1800 . Certainly, the quality of land was improved by draining, irrigating, etc., and the intensity of land use consequently grew. Nevertheless, the extent of land in the 1950s defines the potential resource base. For instance, in England and Wales, between 1688 and 1960, there was a reduction of rough pasture (called 'waste and common' by Gregory King) and a corresponding increased in improved farm land, but the total land available for agriculture remained the same according to King and the recent estimates. Cf. Allen 1994, p. 104 and Stamp 1965, p. 30.

${ }^{8}$ However, Bairoch reports figures for the U.K. rather than England and Wales. Population totals for that Kingdom were taken from Hatcher (1977) and Wrigley and Schofield (1981, p. 528-9). I followed Wrigley and Scholfield's (1981, p. 566) lead in increasing their estimates for England (excluding Monmouthshire) by $6 \%$ to include Wales. The adjustment is rough but agrees with de Vries's (1984, p. 36) figures. 
War II boundaries. Dividing agricultural land by the population gives the land-labour ratio T/L.

Technology

The productivity record of early modern manufacturing was mixed; however, some important advances were made in textiles, which were the most importance products of the age. These improvements affected growth through trade.

The commercial revolution of the seventeenth century was an intra-European affair, and the changing locus of textile production was central to it. In the middle ages, woolen cloth was produced in the cities of Italy and Flanders and exported across the continent. The English were also successful in exporting heavy broadcloths. By the sixteenth century, the English and the Dutch were beginning to make the 'new draperies' which were light worsteds. These were patterned after Italian fabrics. The northern imitations were so successful that English and Dutch exports drove Italian producers out of business in the seventeenth century (Rapp 1975, Harte 1997). New manufacturing industries were established in East Anglia and the Low Countries. The Norwich industry was started in the middle of the sixteenth century by Flemish refugees, although it drew on an earlier craft tradition (Munro 1997, Holderness, 1997, Martin 1997). At the end of the seventeenth century, about $40 \%$ of England's woolen cloth production was exported, and woolen fabrics amounted to $69 \%$ of the country's exports of domestic manufactures (Deane 1957, pp. 209-10, Davis 1954, p. 165). Wool was even more important for London. The new draperies flowed out of the capital: Cloths amounted to 74\% of London's exports and reexports in the 1660s (Rapp 1975, p. 502) and made a large contribution to the growth of that city.

Productivity growth in textiles can be measured with prices. Figure 4 plots an index of input prices (a geometric average of the price of wool and the wage rate) divided by the price of cloth. There was no growth in efficiency in the production of traditional woolen broadcloth for the entire early modern period, while productivity rose $70 \%$ in the new draperies from the inception of production until they became established in the 1620s. Since the English and Italians were paying similar wages and were buying wool and selling cloth in the same markets, their efficiency was similar before the invention of the new draperies. ${ }^{9}$ The rising efficiency of English worsted production compared to traditional woolens is, thus, also indicative of the increasing advantage enjoyed by northern European worsted producers vis-a-vis the Italians.

Enclosure

The enclosure of the open fields and commons is the most well known aspect of the English agricultural revolution, and it is measured by ENCL, the proportion of land enclosed. England is famous as the only country that had an enclosure movement in this period, but it was not the only country with enclosed farms. Indeed, there was considerable variation in the fraction of land enclosed as shown by a map drawn up by Pounds (1990, p. 335). For countries besides England, the fraction of land enclosed is taken from this map; for England, where the proportion grew over time, Wordie's (1983) estimates have been used with slight adjustment to

${ }^{9}$ The cloth market was highly integrated, for, as Munro (1997, pp. 82-3) reports, the cost of shipping woolens between the North Sea and Mediterranean ports was $15 \%$ of their value and often less during the fourteenth century. 
match the dates in the data set. Including ENCL in cross-national regressions explaining agricultural productivity provides a focused test of England's most distinctive rural institution.

Intercontinental Trade volume

Some countries were successful in the race for empire, while others were not. Spain seized a vast empire in Latin America and the Phillippines, England acquired much of north America, some rich sugar islands in the Carribean, and Bengal, the Netherlands conquered Indonesia, the original Spice Islands and Surinam, and France had important possessions in North America, the Carribean, and India. Portugal had a substantial empire in Brazil, Africa, and South Asia but is not in the data base analyzed here. The other European countries were not in the running.

The effect of empires is measured by TRADEPOP, the volume of nonspecie trade per capita. ${ }^{10}$ All of the countries were mercantilist and tried to reserve trade with their colonies for their nationals. The experience of the Dutch is the exception that proves the rule. They were highly efficient in shipping and the closest to free traders in the Atlantic economy (but not in the Asian). However, the Dutch were squeezed out of most Atlantic colonial trade by the regulations of the English, French, and Spanish. Only in times of war could the Dutch make much headway (De Vries and van der Woude 1997, pp. 476-9). Many factors affect trade volumes, but the experience of the Dutch shows the primary of politics in this period, which is why trade is treated as an exogenous measure of imperial advantage.

It should be noted that trade volumes are measured exclusive of shipments of gold and silver. This affects the measurement of Spanish trade where bullion was the main cargo. While the Dutch and, especially, the English empires offered trade and markets, the Spanish may have been too successful in generating loot: The gold and silver from the American inflated prices and wages in Spain rendering much manufacturing unprofitable (Hamilton 1934, 1936, 1947, Dreilichman 2002). The effects of the Spanish empire are tested in some specifications by including a dummy variable SPANEMP.

literacy

The early modern period saw the invention and spread of printing with moveable type, an increase in book publishing, and a concomitant rise in the ability to read and write. The proportion of the population that could sign their name has been established for most parts of Europe in the seventeenth and eighteenth centuries, and that fraction provides a rough indicator of literacy (Table 2). Data for 1500 are less satisfactory, but literacy was clearly far lower no matter how they are processed. Literacy increased in all parts of Europe during the intervening three centuries, but especially in the north where economic growth was most pronounced. Casual speculation suggests that the ability to read and write contributed to technological progress, and this opinion draws some strength from the studies of twentieth century economic

${ }^{10}$ Trade volumes were derived from Deane and Cole (1969, p. 87), Levasseur (1911, vol. I, p. 518, Vol. II, p. 20-2, 94-6), Haudrere (1989, Vol. 4, p. 1201), Villiers (1991, p. 211), De Vries and van der Woude (1997, pp. 393, 445, 460, 474, 478), Garcia Fuentes (1980), Morineau (1985, pp. 267, 494), Hamilton (1934, pp. 33-4), Fisher (1985, pp. 67-8, 1997, pp. 164-70, 201$6)$. 
growth that identify schooling and human capital as important causes. ${ }^{11}$ Could the same have been true of the pre-industrial economy? The answer appears to be 'no' which is why literacy does not appear in the flow diagram in Figure 3.

absolutism

European political systems varied enormously from 1300 to 1800 . I have followed the classification of De Long and Schleifer (1993) who have distinguished 'princes' (absolutist monarchs) from more representative and other systems. Medieval Italy, the Dutch Republic, and eighteenth century England were the classic 'representative' states. Most of the rest were absolutist 'princes' 12 .

DeLong and Schliefer did not categorize Poland, but it is necessary to do so for the present analysis. Poland is an interesting case, for its government was representative with an exceptionally weak monarch up until its dismemberment, which was completed in the 1790s. Before 1800, I have put Poland in the 'nonprince' category. In 1800, I have assigned it to the 'prince' category, for Russia, Prussia, and Austria were all absolutist states.

\section{modeling success}

Five equations explain the five endogenous variables--the real wage, agricultural productivity, urbanization, proto-industrialization, and the population. Since the first four equations comprise a simultaneous system, they are estimated by two stage least squares (instrumental variables). The instruments are all the exogenous variables in the model--LNTL, TRADEPOP, SPANEMP, ENCL, ENG18, LIT, MANPROD, PRINCE, LNURBLG, and the constant. All equations are exactly or over identified by the order condition. I begin with the four equations solved simultaneously in each time period and then consider the equation explaining population growth.

Wage equation

The wage equation is key, for the divergence between north and south is ultimately a question of labour income. Figure 5 defines the problem. $\mathrm{D}$ is the demand curve for labour in pre-industrial society. Since the land area is fixed, diminishing returns implies that a larger population can be employed only if the wage falls. For that reason, the demand curve slopes downward. S represents the supply of labour, which is shown as inelastic (equivalent to the population) for simplicity. With $\mathrm{S}$ at a low level, the wage is high at $\mathrm{w}$. In most of Europe, the population expanded between 1500 and 1800, and the wage fell from $\mathrm{w}$ to $\mathrm{w}_{1}$ as was shown in Figure 5. In the successful economies, however, the story was different. There the demand curve for labour shifted to the right (to $\mathrm{D}_{1}$ ) in step with the population growth. As a result, the wage remained at $\mathrm{w}$. The key question in early modern economic history is why the demand curve for labour grew in a few countries and remained constant in the rest. Answering that

\footnotetext{
${ }^{11}$ The discussion is voluminous and runs from Denison (1962) to Barro (1997).
}

${ }^{12}$ Implicitly, they have categorized Napoleon as a prince, and I have followed that lead, so France in 1800 is put in the 'prince' category. Likewise, the Netherlands in 1800 are classified the same way since the country was a dependency of France. 
question will explain the great divergence in incomes that occurred in the early modern period.

The demand curve in Figure 5 shifts to the right if capital per worker increases or efficiency rises. The model can be implemented empirically by choosing proxies for these variables. Regression 1 in Table 3 provides a basic specification in which the wage ${ }^{13}$ depends on two variables indexing efficiency and capital per worker--the logarithm of agricultural total factor productivity (LNAGTFP) and the log of the urbanization rate (LNURB)--as well as on the $\log$ of the land-labour ratio (LNTL). The latter captures the fall-off in productivity as population presses more heavily on the resource base. This effect explains the downward slope of the demand curve in Figure 5. The coefficients of all variables are positive and statistically significant, as expected, and the equation fits the data reasonably well.

More variables were added to the basic regression in other specifications. Regression 2 contains PRINCE, a dummy variable equaling one for absolutist monarchies. Its coefficient is negative but very small and statistically insignificant indicating that absolutism had a negligible impact on the demand for labour. Regression 3 includes LIT (the fraction of the adult population that could sign its name), TRADEPOP (intercontinental commodity trade per capita), and LNPROTO (the fraction of the population in rural, nonagricultural activities). None of these variables was statistically significant. It is particularly important that neither representative government nor literacy was a variable shifting the demand for labour to the right.

agricultural productivity equation

There are two approaches to explaining the growth in agricultural productivity. The traditional view, discussed previously, attributes agricultural revolutions to the 'modernization' of rural institutions. This approach, however, has been called into question by the micro studies that have shown that rural institutions did not influence efficiency. If agrarian institutions, which limit the responsiveness of agriculture to new opportunities, do not explain why some countries were more productive than others, then differences in the challenges faced by agriculture may explain the differences in performance. The second approach attributes high agricultural productivity to the growth of the nonagricultural economy. Large cities and rural industries increased the demand for food, flax, wool, leather, and labour thereby providing an incentive to farmers to modernize their methods. Von Thunen noticed that agriculture was more intensive near cities, and the second approach generalizes that observation into a theory of agricultural development (Grantham 1978, 1989, Campbell 2000, pp. 411-440). The growth of the nonagricultural economy may, thus, explain agricultural productivity.

This paper measures the relative importance of agrarian institutions and the

${ }^{13}$ The wage is the daily wage of a craftsman converted to the constant purchasing power with an inter-national, inter-temporary consumer price index. The sources of most wages, prices, and the consumer price index are described in Allen (2001). The series for southern and northern English towns are not described in Allen (2001). The former is the Phelps Brown and Hopkins (1955) series; the latter is from Woodward (1995, pp. 250-75). The York series was used for the fifteenth through seventeenth centuries, but it did not differ materially from any of the other, northern series. For the eighteenth century, Gilboy's (1934, pp. 283-7) Lancashire wages were used. All of the English wage series were deflated with the same consumer price index. 
nonagricultural economy in raising farm efficiency by including indicators of both in the statistical model. In Table 4, regression 1, agricultural total factor productivity is regressed on LNURB, LNPROTO, and LNWAGE. They are indices of the growth of the nonagricultural economy. All have positive and statistically significant coefficients. Larger values for the first two variables indicate greater demands on agriculture for food and fibre, while higher wages provide an incentive to shed low productivity jobs or to increase efficiency in other ways in order to generate enough net income to keep the farm labour force from migrating to the city. Regression 1 substantiates the view that a larger nonagricultural economy induced an increase in farm efficiency.

The role of agrarian institutions in limiting the response to these demands is ascertained by including two additional variables in equation 2-4. The first is ENCL, the fraction of land enclosed. Its coefficient was usually about .18. ENCL was statistically significant at about the $15 \%$ level, which is low by most standards. There is, however, much to be said in favour of the coefficient. The value of .18 implies that the total factor productivity of enclosed farms was $18 \%$ higher than that of open fields. If rent accounted for one third of revenues, then enclosure would have boosted rent by $64 \%$, e.g. a rise from 12 shillings to 20 shillings per acre. This result is consistent with rent differences like those observed in some districts in the south midlands (Allen 1992, p. 172, 1999) but a bit higher than Clark's (1998) recent findings. Arthur Young would have been enthusiastic about the regression coefficient, for it is close to the doubling he often spoke of. Despite the low t-ratios, ENCL will be included in the model both as a tribute to Young and to make sure that enclosure gets its due.

The second variable representing agrarian institutions was ENG18, a dummy variable equaling one for eighteenth century England. At this time, England's distinctive agrarian institutions--its great estates, large scale farms, and landless labourers--reached their fully developed form. If they mattered, presumably, they would have pushed English efficiency above the level implied by the other variables. However, the coefficient of ENG18 is always negative, close to zero, and statistically insignificant. This finding contradicts the importance of England's eighteenth century institutions as a source of agricultural improvement.

Finally, PRINCE and LIT were included to see if they had any observable effect on agricultural productivity growth. They did not in any specification.

urbanization equation

The fraction of the population living in cities changed very little in many countries during the early modern period, while rising in the Netherlands and, especially, in England. It is difficult to find one equation that captures both stasis and dynamism. ${ }^{14}$ The problem is made more difficult by the collinearity among important variables in northwestern Europe. This is a bigger problem for this equation than for others.

Table 5 reports regressions that explain Europe's urbanization rate. The lagged urbanization rate LNURBLG is included in all equations to account for the persistence of cities, as will be explained. LNAGTFP is introduced as an explanatory variable since a highly

${ }^{14}$ De Vries (1988) and Bairoch (1988) provide magisterial overviews of European urbanization. See Sweet (1999), Chalklin (2001), and Ellis (2001) for recent surveys of English urbanization in this period. 
productive agriculture might have nurtured cities by providing them with food, raw materials, capital, and labour. TRADEPOP was included to measure the contributions of American and Asian empires, and SPANEMP is included to detect any further effects of the Spanish empire. PRINCE and LIT measure the impact of absolutism and literacy on urbanization. MANPROD measures the productivity of the new draperies relative to traditional woolen cloth and thus the productivity advantage of northern textiles.

The log of the urbanization rate lagged a century (LNURBLG) is a significant variable in all regressions with a coefficient of about .8. Lagged urbanization captures the persistence of city size since its coefficient means that the urban fraction would have been $80 \%$ of its value a century earlier if nothing else had caused it to change.

Persistence represents several social processes. The most common case was countries like Austria or Germany where the urban fraction was low and remained so--in other words where growth was modest. A more interesting case is Italy where the accumulation of social capital allowed cities to renew themselves even when their economic base collapsed. In the middle ages, a major Italian industry woolen cloth. Its manufacture was destroyed by the exports of the new draperies from northern Europe. The Italian cities did not disappear, however. Instead, their economies were recreated on the basis of silk. This involved raising silkworms in the countryside as well as weaving silk cloth in the city. While different technical skills were involved, business skills and networks carried over from wool production. Italians showed tremendous enterprise in the seventeenth century, but it was one step forward for two steps back, and the economy as a whole did not advance.

The urban fraction also remained high in Spain throughout the early modern period, but the reason was different. The manufacturing industries that sustained the medieval cities were destroyed by the inflation caused by American bullion imports. Their population losses were counterbalanced by the growth of Madrid as American treasure was used to build the capital (Ringrose 1983). These very different histories are summarized by the inclusion of the lagged urbanization rate.

Lagged urbanization does not, of course, explain the urban revolutions in England and the Netherlands. Equation 1 indicates that higher agricultural productivity significantly increases urbanization, while equation 2 indicates the same thing for intercontinental commodity trade. However, as equation 3 shows, these variables are highly correlated so they are not jointly significant. Adding PRINCE, LIT, SPANEMP, and MANPROD makes for no significant contribution to explanation (equation 4).

The collinearity problem was addressed on the basis of subsidiary simulations. They indicated that the various national histories could be successfully tracked if the coefficients of LNAGTFP, LNURBLG, TRADEPOP, and the intercept were set to the values noted in Table 5. These are all within a standard error of their values in the rest of the table. Equation 5 shows the value implied for the coefficient of PRINCE if these restrictions are imposed, and that is also very close to its unconstrained value. Consequently, in subsequent simulations, equation 5 is used for urbanization. With this specification, urbanization depends on its lagged value, agricultural productivity, the volume of intercontinental trade, and PRINCE, the dummy variable coding absolutism. The latter is not statistically significance but is included, as in the other equations, to give the representative government argument the best possible run for its money.

proto-industry equation 
Proto-industry was not a direct determinant of labour demand, but it influenced wages and other variables through its impact on agricultural productivity. Proto-industry had contradictory causes that reflect its ambiguous role in early modern development. On the one hand, there were large rural manufacturing industries in the leading economies, and these industries played an important role in economic growth. The English woolen cloth industry is a case in point. On the other hand, many rural industries developed in backward regions and left no legacy for industrialization.

The two faced nature of proto-industry is reflected in the statistical analysis of its causes (Table 6). The negative coefficient of LNAGTFP means that proto-industrialization was a consequence of low agricultural productivity rather than high productivity: It was often the occupation of poor peasants practicing a backward agriculture as in central Europe (Table 1). The negative coefficient on LNWAGE conveys the same lesson.

Why, then, was there a proto-industrial revolution in Northwestern Europe? Table 6 shows that MANPROD, which indexes the growth in productivity in the new draperies, offset the depressing effect of high productivity agriculture. The proximate cause of northwestern Europe's proto-industrial revolution was, thus, quite different from the cause of its urban revolution. The former was due to rising productivity in textile manufacturing in the sixteenth and seventeenth centuries, while the latter was due, in the first, instance, to empire.

Manufacturing productivity did not directly promote urban growth, nor did empire promote rural manufacturing. It should be emphasized, however, that these are "first round" effects. Allowing for feedback between the sectors means that all exogenous variables affected urbanization and proto-industrialization, sometimes in dramatic ways.

Equations 2 and 3 also include PRINCE. Its coefficient in these tables is larger in absolute value than in the other tables and almost statistically significant by the usual criteria. This is the strongest evidence that absolutism depressed economic development, and equations 2 will be used in simulations to assess its impact.

LIT is included in equation 3, and it remains insignificant.

Population equation

With the data at hand, one cannot explore the determinants of fertility and mortality separately; only the overall impact of wages on population change can be examined. As a first step, the population growth rate over a century was graphed against the real wage at the beginning of that century. Century data are much lower frequency than the annual data usually used in such investigations, but the wage and population cycles have periods of several centuries, so century data can reveal the elements of the system. ${ }^{15}$

Graphical analysis revealed two very different demographic regimes. In England and the Netherlands, population growth clearly rose with the wage-these countries, in other words, exhibited the Malthusian preventive check. The rest of the continent did not: no relationship was discernible between population growth and wages. It may be that other data would reveal Malthusian behaviour, but it is not apparent here.

The graphical analysis was extended with regression models of population growth. Table

${ }^{15}$ For the same reason, Lee (1973) analyzed English data at 50 year intervals. 
7 shows regressions for England and the Netherlands as well as the rest of Europe. Other variables included in the regressions are the urbanization rate, and dummy variables for the Black Death, the thirty years war, and the Netherlands. Urbanization is included in recognition of the very high mortality of cities (Wrigley 1967, Van Zanden 1993). The results are plausible: According to equation 2, population growth increased with the wage and decreased with urban density. Urban density was higher in the Netherlands than in England, and so there is some collinearity between a dummy variable for the Netherlands and urbanization. The t statistic on $\mathrm{DN}$ in equation 2 shows it to be insignificant, so I have used equation 3 in later analysis. This gives a large, negative weight to urbanization in accounting for population change.

The rest of the continent had a different demographic regime according to this regression analysis. As equations 4 and 5 indicate, neither the wage nor urban density had an appreciable impact. The equation predicts population growth of about $24 \%$ per century $(0.2 \%$ per annum) over much of Europe irrespective of economic conditions. The fourteenth century aside, population growth in northwestern Europe varied between nil and 50\% per century on account of changes in the wage and urbanization. The mean was similar, but the sensitivity to economic conditions was more Malthusian.

\section{Divergent Paths to the Nineteenth Century}

An important test of the simulation model is to see whether it can account for the different paths of development followed by different parts of Europe. If the model is simulated from 1400 onward, do Italy and France show falling wages and limited structural transformation? Do the Netherlands and England maintain their wages and exhibit urban and agricultural revolutions? The questions have been addressed using simulations with the five equation verison of the model in which population is endogenous and with a four equation version in which population is treated as exogenous. The answers are similar in both cases, but the model with endogenous population introduces some erratic movements in simulated wages when there are discrepancies in simulating population. The simulations of the other variables are scarcely affected. I will concentrate on the model with exogenous population and consider the effects of endogenous population at the end of the discussion.

Figures 6-8 compare simulated trajectories for urbanization, agricultural productivity, and wages for England, Italy, France, and the Netherlands. ${ }^{16}$ The simulations for France are very similar to those for Germany, Austria, and Poland. They show little cumulative urbanization, static agricultural productivity, and falling real wages. For France and the major countries of central Europe, the model predicts little economic development. The simulations for Italy and Spain are almost as bleak, although their initially higher urban shares are largely maintained.

The simulations for the Netherlands and England, on the other hand, show successful patterns of economic development. In the first place, urbanization was much more extensive. The Dutch were already more highly urbanized in 1500 than much of the continent, and the development of commerce and empire built on that base to produced the highest rate of

\footnotetext{
${ }^{16}$ The simulations use regression 2 in Table 3, regression 3 in Table 4, regression 5 in
} Table 5, regression 2 in Table 6, and regressions 3 and 4 in Table $7 .$. 
urbanization in 1800. The English started from a much lower level of urbanization in 1500 , surpassed France and Italy, and almost caught up to the Dutch by 1800.

Unlike the major continental countries, England and the Netherlands both had agricultural revolutions, and the simulation model reproduces these. Revisionist historians have undermined the view that the modernization of agrarian institutions caused agricultural productivity growth, which, in turn, spurred economic development generally. This paper has taken that reassessment to its logical conclusion by modeling the growth in farm efficiency as a response to the development of the nonagricultural economy. This hypothesis works rather well. It replicates the agricultural revolutions of Northwestern Europe and the stagnation of productivity on much of the continent.

Urbanization, greater farm efficiency, and proto-industrialization had a pronounced impact on wages. In northwestern Europe, the simulated wage remains high during the early modern period. The simulation for England shows a drop in the sixteenth century and then a rebound in the seventeenth and eighteenth as economic development tightened up the labour market. This was escape from the Malthusian trap through rapid development. The contrast for most of the continent is impressive. There, simulated real wages fell as population grew and the economy stagnated.

\section{The Sources of England's Success}

The simulation model can be used to factor out the differences between successful and unsuccessful economies. I concentrate on the comparison between England, the most successful economy, and her large continental rivals like France and Austria. How did England maintain a high wage despite rapid population growth, while continental wages fell even though the population grew little? The possibilities--as incorporated in the model--include: the replacement of absolutist by representative government in the seventeenth century, the enclosure of the open fields, the productivity advantage associate with the new draperies, and the growth in intercontinental trade consequent upon the British empire. ${ }^{17}$ In addition, the prevent check demographic regime may have accelerated economic development. By successively removing these sources of growth and resimulating the model, the fundamental differences between England and the continent are identified. These simulations include the ramifications of the changes throughout the economy and not simply in the sector concerned.

Figures 9-11 show alternative simulations for England of agricultural total factor productivity, the urbanization rate, and the real wage from 1300 to 1800 . In all figures, the top line is the "simulated actual" history of the variable, that is, the value implied by the model when it is simulated with the historical time paths of the variables describing the fraction of the land enclosed, relative textile productivity, and so forth. If the model were perfect, the simulated values would equal their historical time paths. In the event, the main features are replicated.

The lower lines show the simulated value of the variables as growth promoting factors are removed from the calculations. The line marked "not representative" shows the course of the

${ }^{17}$ In principle, development could also be simulated holding literacy at medieval levels. Since the sign of the coefficient of literacy was usually negative, these simulations perversely generate greater growth than actually occurred. However, these simulations have little relevance since the negative coefficients on literacy were never statistically significant. 
variable if England had remained an absolutist monarch in the eighteenth century. The removal of exogenous factors cumulates as one moves down the graphs. Thus, the line marked "no enclosure" keeps the fraction of enclosed land at its 1500 level, while also eliminating representative government. The difference between the "no representative" line and the "no enclosure" line, therefore, shows the impact of enclosure. By the same reasoning, the bottom line labeled "no intercontinental trade" shows the result of eliminating all four growth promoting factors.

Figures 9-11 make several important points about England's success. First, the bottom lines trace out a no-growth trajectory like that of the large continental countries: little growth in agricultural productivity or the urban share and a falling real wage. In the absence of the growth-promoting factors, in other words, the history of England would have been like that of France, Germany, or Austria.

Second, the ascendancy of parliament in the eighteenth century made little contribution to England's development. Several studies of interest rates have failed to detect any growthpromoting result of the Glorious Revolution of 1688 (Clark 1996, Epstein, 2000, pp. 12-37, Quinn 2001), and the present study supports that view.

It is not surprising that representative government did not accelerate growth. Property was secure in all the leading European countries, whatever their constitution. Indeed, as Rosenthal (1990) has shown, one of France's problems was that property was too secure: the state, for instance, could not push forward profitable irrigation projects in Provence because land owners could block these initiatives in the courts. Parliamentary ascendancy in England led to higher taxes than in France, contrary to the views of liberals then or now (Mathias and O'Brien 1976, 1978, Hoffman and Norberg 1994, Bonney 1999). And while representative government could provide good government-England's local improvement acts are a case in point-it could also provide spectacularly bad government. The concentration of power in the diet emasculated the Polish state and ultimately destroyed it. It would be a great surprise if there were a straight forward statistical relationship between absolutism and underdevelopment, and there was not in these tests.

Third, the enclosure movement made little contribution to England's progress. In all cases, the "no enclosure" trajectory grows almost as rapidly as the "simulated actual." Figures 9-11 extend the findings of agricultural historians who downplay the importance of enclosure by showing that it had only a small impact on urbanization, the real wage--and, even, agricultural TFP. This simulation includes not only the direct effect of enclosure on farm efficiency but also the feedback effect when the impact of rising farm efficiency on city growth, for instance, is taken into account. In this broad framework--as well as in the more narrowly defined study of farming methods--the enclosure movement was peripheral to English development.

The converse of this conclusion needs underlining. The success of English agriculture was a response to the growth of the urban and proto-industrial sectors and to the maintenance of a high wage economy. Farmers responded to these challenges by increasing output and by economizing on labour. The latter was effected by increasing the size of farms and by enclosing land to convert arable to pasture. To the degree that these changes, the hallmarks of the English agricultural revolution, increased productivity, they should be seen as responses to an urbanized, high wage economy rather than as autonomous causes. (Dutch agriculture, it should be noted, developed along similar lines for similar reasons.) The traditional historiography, in other 
words, should be stood on its head. ${ }^{18}$

Fourth, the productivity rise underlying the success of the new draperies in the seventeenth century was of great importance for England's success. It provided a strong boost to urbanization, and the growth of rural industry. Through these effects, the success of the new draperies was responsible for a large fraction of the growth in agricultural TFP as farmers successfully responded to the greater demand for food, wool, and labour. Without seventeenth century success, wages, agricultural productivity, and city size would all have been lower in 1800 .

Fifth, the empire established in the seventeenth and eighteenth centuries also contributed to growth. The greatest impact was on city size. Over half of England's urban expansion is attributed to Empire in these simulations.

How are these conclusions affected by demographic considerations? There are two questions to consider. The first is how English population history would have been affected by changes in the development of the economy, and the second is how English history would have differed had England had a continental population regime. Figure 12 summarizes some simulations that highlight the important features. First, the rapid growth of the English economy due to the new draperies and the intercontinental trade boom had an important effect on population growth. This is indicated in Figure 12 by the difference between the "simulated actual" population history and the "no trade" simulation, which eliminates representative government, enclosure, the new draperies, and the trade boom. Without these growth stimulating effects, England's population would have been cut from a simulated 9.2 million in 1800 to 7.5 million. These is the expected result in a preventive check population model where population surges in response to economic expansion.

Second, the substitution of a continental demographic regime would not have had much impact on English development. With continental demography, the population is insensitive to the real wage or urbanization, and so ends up at 8.5 million whatever happens to the economy. If all of the growth-promoting developments occurred, the population would have remained at 8.5 million rather than rising to 9.2 million, while the real wage in England would have been somewhat higher than it actually was. There would have been very little difference in urbanization, proto-industry, or agricultural productivity. A population regime that was less responsive to economic variables would probably have benefitted labour at the expense of landlords and capitalists, but would probably have had little impact on growth. Malthus and Ricardo would not have been surprised.

implications and questions

The simulations show that a simple model captures the factors responsible for success and failure in the early modern economy. The intercontinental trade boom was a key development that propelled northwestern Europe forward. This conclusion has also been advanced by Acemoglu, Johnson, and Robinson (2002). However, this paper emphasizes that

${ }^{18}$ This view is not shared by Crafts and Harley (2002), who argue that capitalist agriculture played an important role in explaining the growth of industrial employment in the British industrial revolution. 
northwestern Europe's ascent began in the century before the American and Asian trades become important. This emphasis extends the work of historians like Davis (1954) and particularly Rapp (1975), who have noted that the commercial revolution began in the seventeenth century before the Atlantic trades became significant and was an intra-European reorganization in which northwestern Europeans out competed Mediterranean producers in woolen textiles. The ascendancy of northwestern Europe and the eclipse of Italy, on this reading of the evidence, predated the rise of the Atlantic economy. Northwestern Europe's success was based on a two step advance-the first within Europe, the second in America and Asia.

This success, it might be noted, marked the first steps out of the Malthusian trap. High wages were sustainable even with pre-industrial fertility so long as the economy grew fast enough. The reason is that the population growth rate was limited to about $2 \%$ per year, the difference between the maximum observed fertility rate (50 per 1000 or $5 \%$ per year) and the mortality rate, which was about $3 \%$ per year in the early modern period. If the demand for labour grew faster than $2 \%$ per year, then wages could rise even without the fertility restraint of twentieth century Europeans. This favourable conjuncture first occurred in England and the low countries in the early modern period when high wages were maintained even as the population expanded at a brisk rate. In the rest of Europe, where population grew less rapidly, wages sagged as the economy stagnated. Rapid economic development, rather than fertility reduction, was the basis of continued high wages.

The simulations reported here have some important lessons for thinking about economic growth. The dominant paradigm in economics circles sees sustained growth as the result of human capital accumulation and invention. These are promoted by limited government. This view receives little support from the analysis of this paper.

The establishment of representative government had a negligible effect on development in early modern Europe. The stress placed on its importance concatenates the form of the constitution, the security of property, low taxes, and good government. These could come in many combinations, however. In England, for instance, most agricultural producers acquired the secure property that was a precondition for the agricultural revolution when royal courts created copyhold and beneficial leasehold tenures in the late fifteenth and sixteenth centuries (Allen 1992, pp. 55-77). This was judicial activism by royal officials rather than the action of parliament. Much of England's rise to preeminence occurred before 1688. The English had displaced the Italians in woolen cloth production by then, and the population of London had exploded from 55 thousand in 1520 to 475 thousand in 1670-that is before the Glorious Revolution (Wrigley 1985). In eighteenth century France, property was secure enough for the Atlantic ports to boom based on intercontinental trade. Would representative government have made them grow faster? Perhaps by voting higher taxes so France could have contested mastery of the seas more successfully and expanded its empire rather than losing it. The possible gains are doubtful, however, since the French population was three or four times that of England (and ten times greater than the Dutch), so that intercontinental trade would have had to have been larger by the same proportion to have had the same per capita effect. French development was not held back by high taxes, the inability to enforce commercial contracts, or royal interference with private credit (Hoffman, Postel-Vinay, Rosenthal 2000). Good government was not cheap nor did it require a parliament.

Likewise, literacy was generally unimportant for growth. What the regression coefficients of literacy measure are its marginal value. The nation-wide adult literacy rate 
reached $50 \%$ when labourers learned to read. Their ability probably had no economic pay-off, and Reis (2000) has argued that they acquired literacy to study religious tracts and enjoy pulp fiction rather than as an investment. The finding of a negligible economic return on the margin is consistent with literacy's having a high value to some merchants and scientists but to few others. This view is consistent with Mitch's (1993) argument that schooling had little pay-off during the industrial revolution, and Sandberg's (1979) observation that literacy was widespread in backward parts of northern Europe like Sweden.

These findings, so jarring to modern expectations, gain plausibility in the light of recent research on science and technology. Mokyr (2002), for instance, has argued that the 'knowledge economy' is a recent phenomenon. Its origins lie in the scientific revolution of the seventeenth century, but it only became significant on a broad scale in the nineteenth. Approaching the matter from a different direction, Goldin and Katz (1998) have traced the origins of 'capitalskills complementarity' to the early twentieth century. Mass literacy was irrelevant to economic growth before these developments.

The results of this paper are much more akin to the findings of recent work on the British industrial revolution. Crafts and Harley $(1992,2000,2002)$ have argued that productivity growth was limited to agriculture and a few leading industrial sectors. Most growth came from structural transformation including the remarkable release of labour from English agriculture. The openness of the economy to international trade was important in explaining this outcome. It might be noted that other historians-e.g. Pomeranz (2000) and Frank (1998)-have also emphasized the importance of the international economy, although their theoretical frameworks are very different. These conclusions all have echoes in the themes of this paper. 
Table 1

Distribution of the Population by Sector, 1500 - 1800

$\begin{array}{cl}1500 & 1800 \\ \text { rural } & \text { rural } \\ \text { nonagri- } & \text { nonagri } \\ \text { urban culture agric } & \text { urban culture agric }\end{array}$

greatest transformation

\begin{tabular}{|c|c|c|c|c|c|c|}
\hline England & .07 & .18 & .74 & .29 & .36 & .35 \\
\hline \multicolumn{7}{|c|}{ significant modernization } \\
\hline Netherlands & .30 & .14 & .56 & .34 & .25 & .41 \\
\hline Belgium & .28 & .14 & .58 & .22 & .29 & \\
\hline \multicolumn{7}{|l|}{ slight evolution } \\
\hline Germany & .08 & .18 & .73 & .09 & .29 & .62 \\
\hline France & .09 & .18 & .73 & .13 & .28 & \\
\hline Austria/Hungary & .05 & .19 & .76 & .08 & .35 & \\
\hline Poland & .06 & .19 & .75 & .05 & .39 & \\
\hline \multicolumn{7}{|l|}{ little change } \\
\hline Italy & .22 & .16 & .62 & .22 & .20 & \\
\hline Spain & .19 & .16 & .65 & .20 & .16 & \\
\hline
\end{tabular}

Source: Allen (2000, pp. 8-9). 
Table 2

\author{
Adult Literacy, $1500-1800$ \\ Proportion of the Adult Population \\ Could Sign Its Name
}

$1500 \quad 1800$

$\begin{array}{lll}\text { England } & .06 & .53 \\ \text { Netherlands } & .10 & .68 \\ \text { Belgium } & .10 & .49 \\ \text { Germany } & .06 & .35 \\ \text { France } & .07 & .37 \\ \text { Austria/Hungary } & .06 & .21 \\ \text { Poland } & .06 & .21 \\ \text { Italy } & .09 & .22 \\ \text { Spain } & .09 & .20\end{array}$

Sources:

1500--estimated from rural-urban breakdown.

Rural population assumed to be 5\% literate. This is suggested by later data from Nalle (1989, p. 71) and Houston (1988, pp. 140-1, 152-3) for Spain, (Wyczanski 1974, p. 713) for Poland, Le Roy Ladurie (1974, pp. 161-4) for Langudoc, Graff (1987, p. 106) for England.

Urban population assumed to be 23\% literate generalizing from Grendler's (1989, p. 46) estimate for Venice in 1587 that 33\% of the men and $12.2 \%-13.2 \%$ of the women were literate for an overall average of $23 \%$. The proportion was of the same order in Valencia (Nalle 1989, p. 71), among the nobles and bourgeoisie of Poland (Wyczanski 1974, p. 713), and perhaps a bit lower in fifteenth century London (Graff 1987, p. 106). The small urban shares in countries besides spain and Italy at this time mean that the urban literacy rate has no discernible impact on the national average.

1800--Data are fuller for the seventeenth and eighteenth centuries and include: Nalle (1989), Houston (1988), Graff 
(1987), Cressy (1980, 1981), Fraga (1990), Grendler (1989), Ruwet and Wellemans (1978), Wyczanski (1974), Francois (1989), Furet and Ozouf (1977), Gelabert (1987), de Vries and van der Woude (1997), Park (1980), Chartier (1987), Cipolla (1969), Kuijpers (1997), Larguie (1987). 


$$
\begin{gathered}
\text { Table } 3 \\
\text { Wage Equation } \\
\text { (T-ratios in parentheses) }
\end{gathered}
$$

\begin{tabular}{|c|c|c|c|}
\hline regression & 1 & 2 & 3 \\
\hline dep var: & LNWAGE & LNWAGE & LNWAGE \\
\hline estimator: & IV & IV & IV \\
\hline LNTL & $\begin{array}{r}.42 \\
(5.84)\end{array}$ & $\begin{array}{r}.40 \\
(4.59)\end{array}$ & $\begin{array}{r}.19 \\
(1.64)\end{array}$ \\
\hline LNURB & $\begin{array}{c}.22 \\
(3.24)\end{array}$ & $\begin{array}{c}.23 \\
(3.17)\end{array}$ & $\begin{array}{c}-.11 \\
(-.61)\end{array}$ \\
\hline LNAGTFP & $\begin{array}{c}.60 \\
(2.68)\end{array}$ & $\begin{array}{c}.54 \\
(1.98)\end{array}$ & $\begin{array}{c}1.03 \\
(3.25)\end{array}$ \\
\hline PRINCE & & $\begin{array}{c}-.03 \\
(-.43)\end{array}$ & $\begin{array}{c}-.09 \\
(-1.07)\end{array}$ \\
\hline LNPROTO & & & $\begin{array}{c}-.66 \\
(-1.78)\end{array}$ \\
\hline LIT & & & $\begin{array}{c}-.01 \\
(-.01)\end{array}$ \\
\hline TRADEPOP & & & $\begin{array}{c}-.01 \\
(-.08)\end{array}$ \\
\hline constant & $\begin{array}{c}-.86 \\
(-1.51)\end{array}$ & $\begin{array}{c}-.66 \\
(-.88)\end{array}$ & $\begin{array}{c}-.86 \\
(-.83)\end{array}$ \\
\hline$R^{2}$ & .60 & .59 & .65 \\
\hline
\end{tabular}


Table 4

Agricultural Productivity Equation

( $\mathrm{T}$-ratios in parentheses)

\begin{tabular}{|c|c|c|c|c|}
\hline $\begin{array}{l}\text { regression } \\
\text { dep var: }\end{array}$ & $\begin{array}{c}1 \\
\text { LNAGTFP }\end{array}$ & $\begin{array}{c}2 \\
\text { LNAGTFP }\end{array}$ & $\begin{array}{c}3 \\
\text { LNAGTFP }\end{array}$ & $\begin{array}{c}4 \\
\text { LNAGTFP }\end{array}$ \\
\hline estimator: & IV & IV & IV & IV \\
\hline LNURB & $\begin{array}{c}.27 \\
(5.68)\end{array}$ & $\begin{array}{c}.24 \\
(4.61)\end{array}$ & $\begin{array}{c}.23 \\
(4.27)\end{array}$ & $\begin{array}{c}.50 \\
(1.84)\end{array}$ \\
\hline LNPROTO & $\begin{array}{c}.55 \\
(4.39)\end{array}$ & $\begin{array}{c}.43 \\
(3.08)\end{array}$ & $\begin{array}{c}.50 \\
(3.06)\end{array}$ & $\begin{array}{c}1.19 \\
(1.74)\end{array}$ \\
\hline LNWAGE & $\begin{array}{c}.47 \\
(3.02)\end{array}$ & $\begin{array}{c}.33 \\
(1.90)\end{array}$ & $\begin{array}{c}.44 \\
(2.00)\end{array}$ & $\begin{array}{c}.50 \\
(1.35)\end{array}$ \\
\hline ENG1 8 & & & & $\begin{array}{c}-.31 \\
(-1.01)\end{array}$ \\
\hline ENCL & & $\begin{array}{c}.19 \\
(1.56)\end{array}$ & $\begin{array}{r}.18 \\
(1.53)\end{array}$ & $\begin{array}{c}.35 \\
(1.36)\end{array}$ \\
\hline PRINCE & & & $\begin{array}{l}.06 \\
(.84)\end{array}$ & $\begin{array}{l}.05 \\
(.37)\end{array}$ \\
\hline LIT & & & & $\begin{array}{c}-1.28 \\
(-1.01)\end{array}$ \\
\hline constant & $\begin{array}{c}.63 \\
(2.03)\end{array}$ & $\begin{array}{c}.58 \\
(1.98)\end{array}$ & $\begin{array}{c}.40 \\
(1.10)\end{array}$ & $\begin{array}{c}2.16 \\
(1.22)\end{array}$ \\
\hline $\mathrm{R}^{2}$ & .53 & .58 & .58 & .29 \\
\hline
\end{tabular}




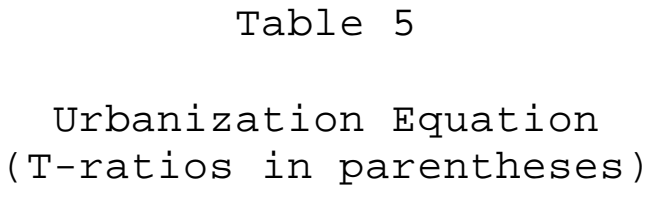

Note:

The dependent variable in regression 5 is LNURBCON = LNURB $.14 *$ TRADEPOP $-.79 *$ LNURBLG $-.41 *$ LNAGTFP +.46 . The values of the independent varialbles in this equation are thus constrained to the values in the definition of LNURBCON. 


\begin{tabular}{|c|c|c|c|}
\hline \multirow{3}{*}{$\begin{array}{l}\text { regression } \\
\text { dep var: }\end{array}$} & \multicolumn{3}{|c|}{$\begin{array}{l}\text { Proto-Industry Equation } \\
\text { (t-ratios in parentheses) }\end{array}$} \\
\hline & 1 & 2 & 3 \\
\hline & LNPROTO & LNPROTO & LNPROTO \\
\hline estimator: & IV & IV & IV \\
\hline LNAGTFP & $\begin{array}{c}-1.14 \\
(-1.98)\end{array}$ & $\begin{array}{c}-.93 \\
(-1.58)\end{array}$ & $\begin{array}{r}-.94 \\
(-.83)\end{array}$ \\
\hline LNWAGE & $\begin{array}{c}-.84 \\
(-3.67)\end{array}$ & $\begin{array}{c}-.99 \\
(-4.02)\end{array}$ & $\begin{array}{c}-1.00 \\
(-1.62)\end{array}$ \\
\hline MANPROD & $\begin{array}{c}1.48 \\
(3.29)\end{array}$ & $\begin{array}{c}1.27 \\
(2.76)\end{array}$ & $\begin{array}{c}1.35 \\
(2.57)\end{array}$ \\
\hline PRINCE & & $\begin{array}{c}-.18 \\
(-1.49)\end{array}$ & $\begin{array}{r}-.16 \\
(-.96)\end{array}$ \\
\hline LIT & & & $\begin{array}{r}-.14 \\
(-.10)\end{array}$ \\
\hline TRADEPOP & & & $\begin{array}{l}.004 \\
(.02)\end{array}$ \\
\hline SPANEMP & & & $\begin{array}{l}(-.08) \\
(-.21)\end{array}$ \\
\hline constant & $\begin{array}{l}-1.41 \\
(-2.01)\end{array}$ & $\begin{array}{l}-.80 \\
(-1.00)\end{array}$ & $\begin{array}{l}-.84 \\
(-.58)\end{array}$ \\
\hline $\mathrm{R}^{2}$ & .37 & .42 & .40 \\
\hline
\end{tabular}




\section{Table 7}

Population Growth Equations

(t ratios in parentheses)

\begin{tabular}{|c|c|c|c|c|c|}
\hline regression & 1 & 2 & 3 & 4 & 5 \\
\hline region: & Eng/Neth & Eng/Neth & Eng/Neth & cont & cont \\
\hline dep variable: & : POPGROW & V POPGROW & POPGROW & POPGROW & POPGROW \\
\hline CONSTANT & $\begin{array}{l}-.47 \\
(-.89)\end{array}$ & $\begin{array}{l}.15 \\
(.29)\end{array}$ & $\begin{array}{c}.43 \\
(1.11)\end{array}$ & $\begin{array}{c}1.25 \\
(16.35)\end{array}$ & $\begin{array}{c}1.25 \\
(16.11)\end{array}$ \\
\hline WAGE & $\begin{array}{c}.21 \\
(3.13)\end{array}$ & $\begin{array}{c}.16 \\
(2.65)\end{array}$ & $\begin{array}{c}.14 \\
(2.65)\end{array}$ & $\begin{array}{l}-.0016 \\
(-.17)\end{array}$ & $\begin{array}{l}-.00029 \\
(-.03)\end{array}$ \\
\hline URBRATE & $\begin{array}{l}.68 \\
(.44)\end{array}$ & $\begin{array}{l}-.62 \\
(-.43)\end{array}$ & $\begin{array}{l}-1.58 \\
(-2.20)\end{array}$ & & $\begin{array}{l}-.07 \\
(-.27)\end{array}$ \\
\hline $\mathrm{DBD}$ & & $\begin{array}{c}-.58 \\
(-2.00)\end{array}$ & $\begin{array}{c}-.68 \\
-2.70)\end{array}$ & $\begin{array}{c}-.51 \\
(-3.85)\end{array}$ & $\begin{array}{c}-.51 \\
(-3.70)\end{array}$ \\
\hline DN & $\begin{array}{c}-.64 \\
(-1.53)\end{array}$ & $\begin{array}{l}-.30 \\
(-.80)\end{array}$ & & & \\
\hline D 30 & & & & $\begin{array}{c}-.25 \\
(-1.89)\end{array}$ & $\begin{array}{c}-.25 \\
(-1.81)\end{array}$ \\
\hline $\mathrm{R}^{2}$ & .64 & .80 & .77 & .36 & .36 \\
\hline
\end{tabular}

Note: The dependent variable is the ratio of the population at one time to its value a century earlier. Equations 1-3 were estimated for England and the Netherlands, while equations 4 and 5 were estimated for the remaining continental countries.

WAGE = real wage

URBRATE = fraction of the population living in cities

DBD = dummy variable for Black Death

$\mathrm{DN}=$ dummy variable for the Netherlands

D30 = dummy variable for the thirty years war 
Figure 1

Real Nages, 12DD-185D

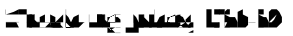

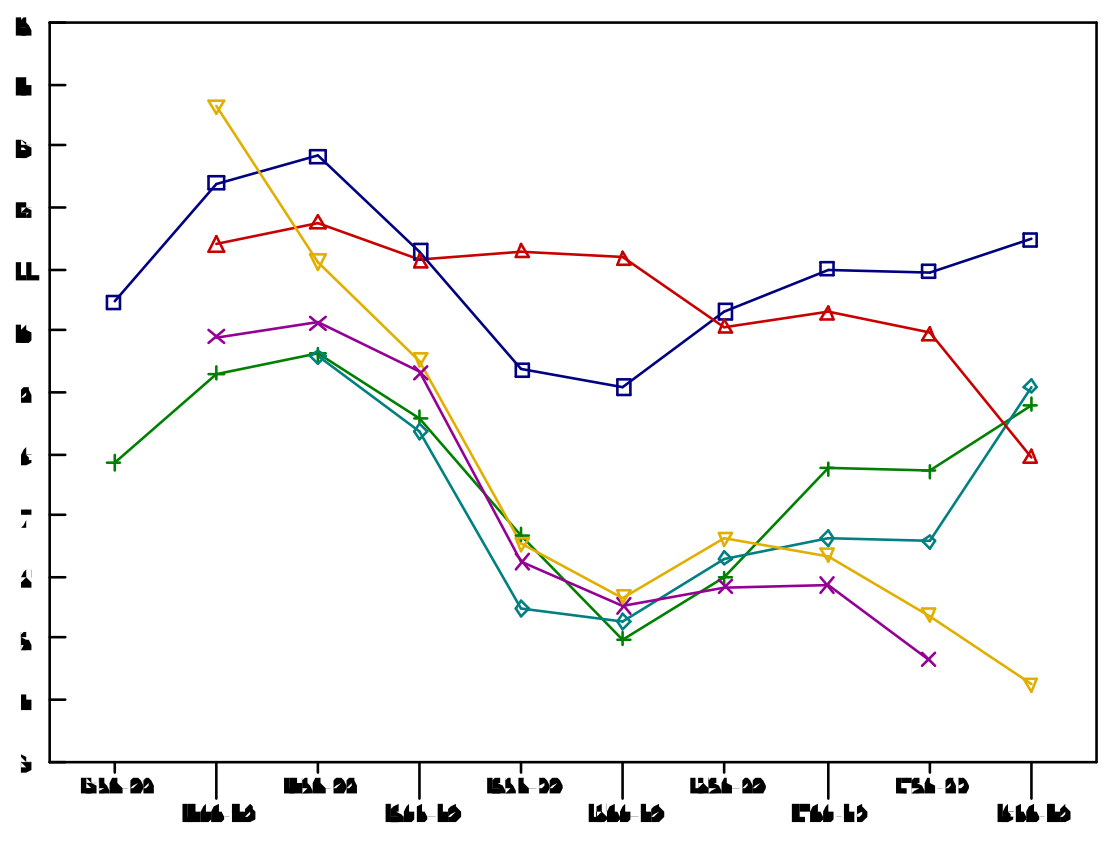

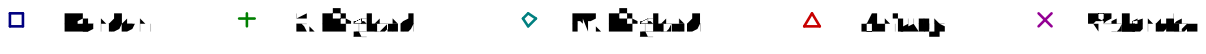


Figure 2

\section{Agriculisural Tos facior Probuesirin bob uts}
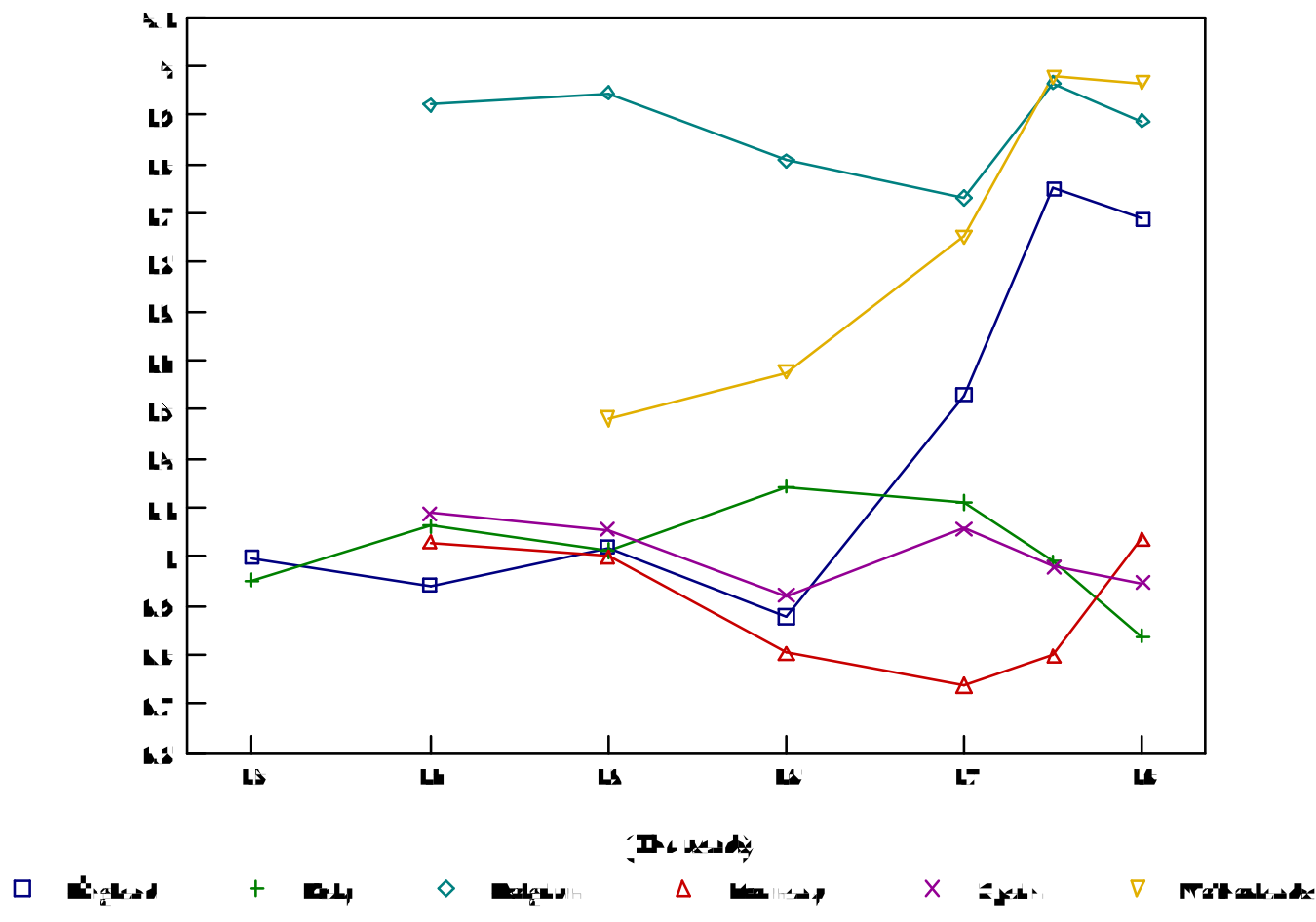
Figure 3

Flow Chart (One Period) of the Model

Exogenous Variables

Endogenous Variables
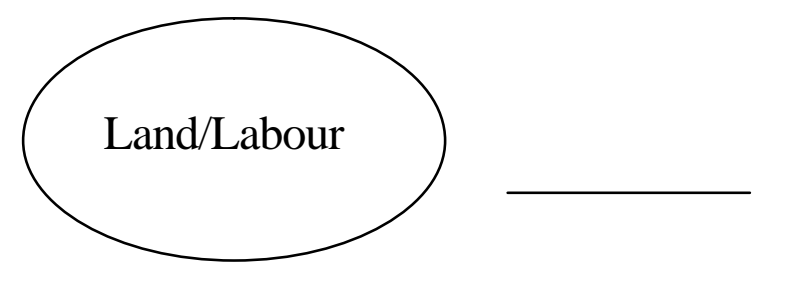

Manufacturing

Productivity
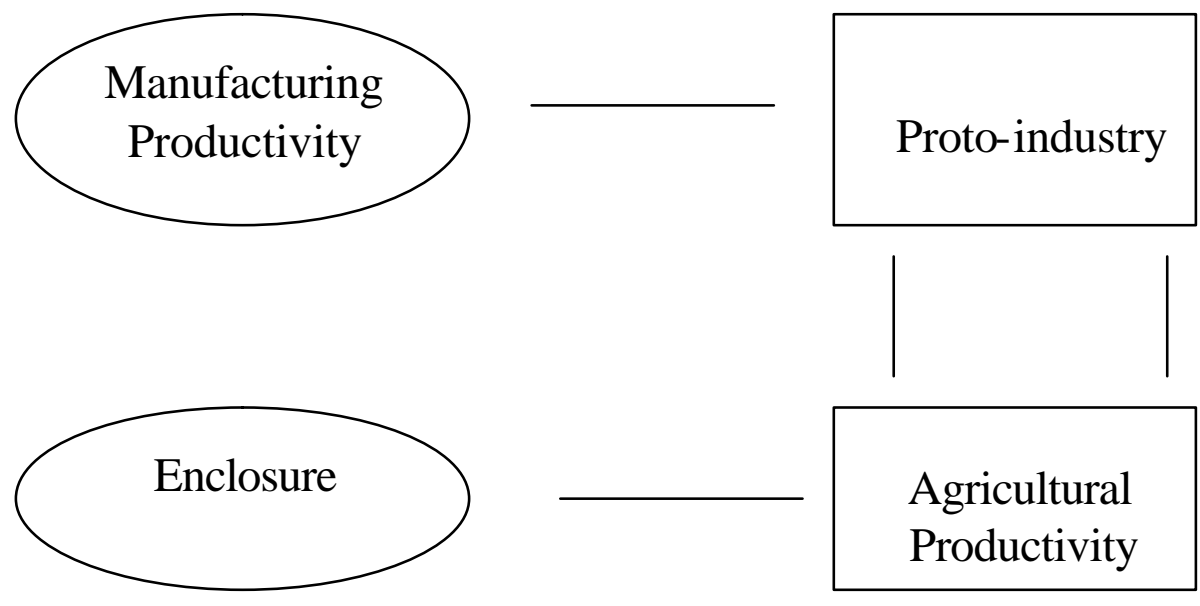

Agricultural

Productivity

Trade Boom
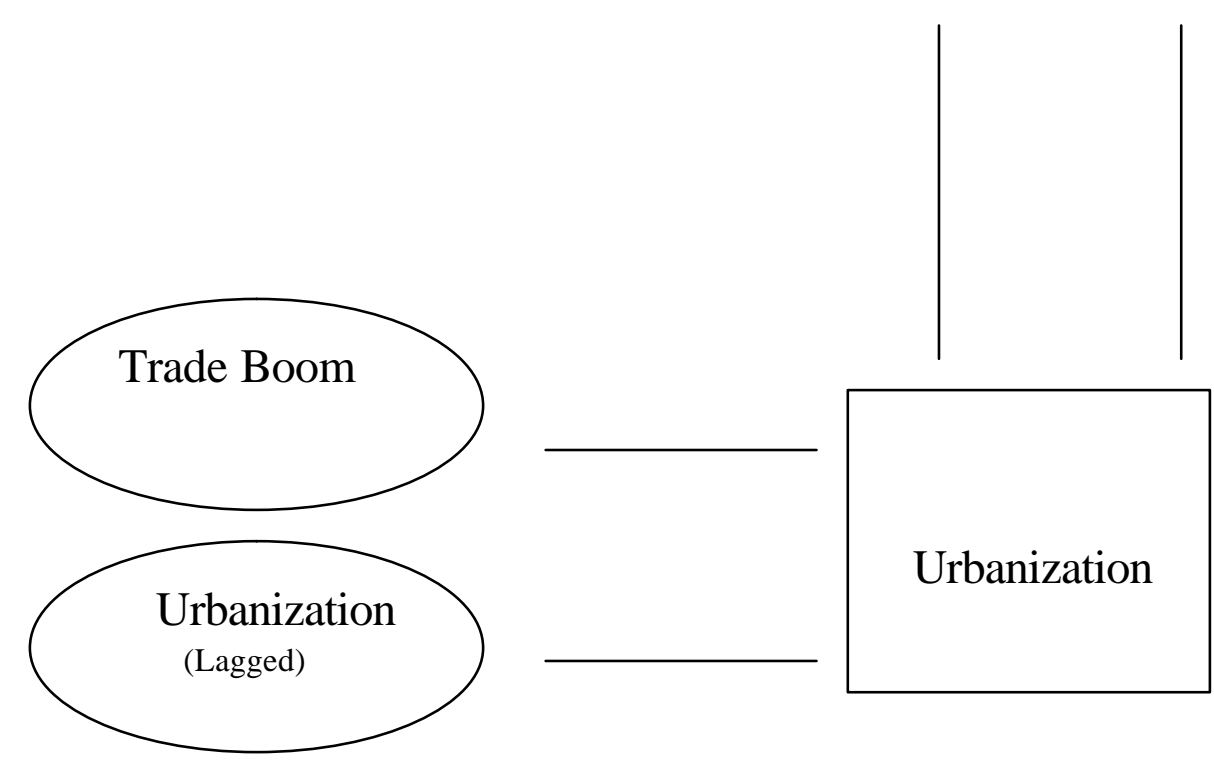
Figure 4

\section{Toial Produciivin in English Eloih}

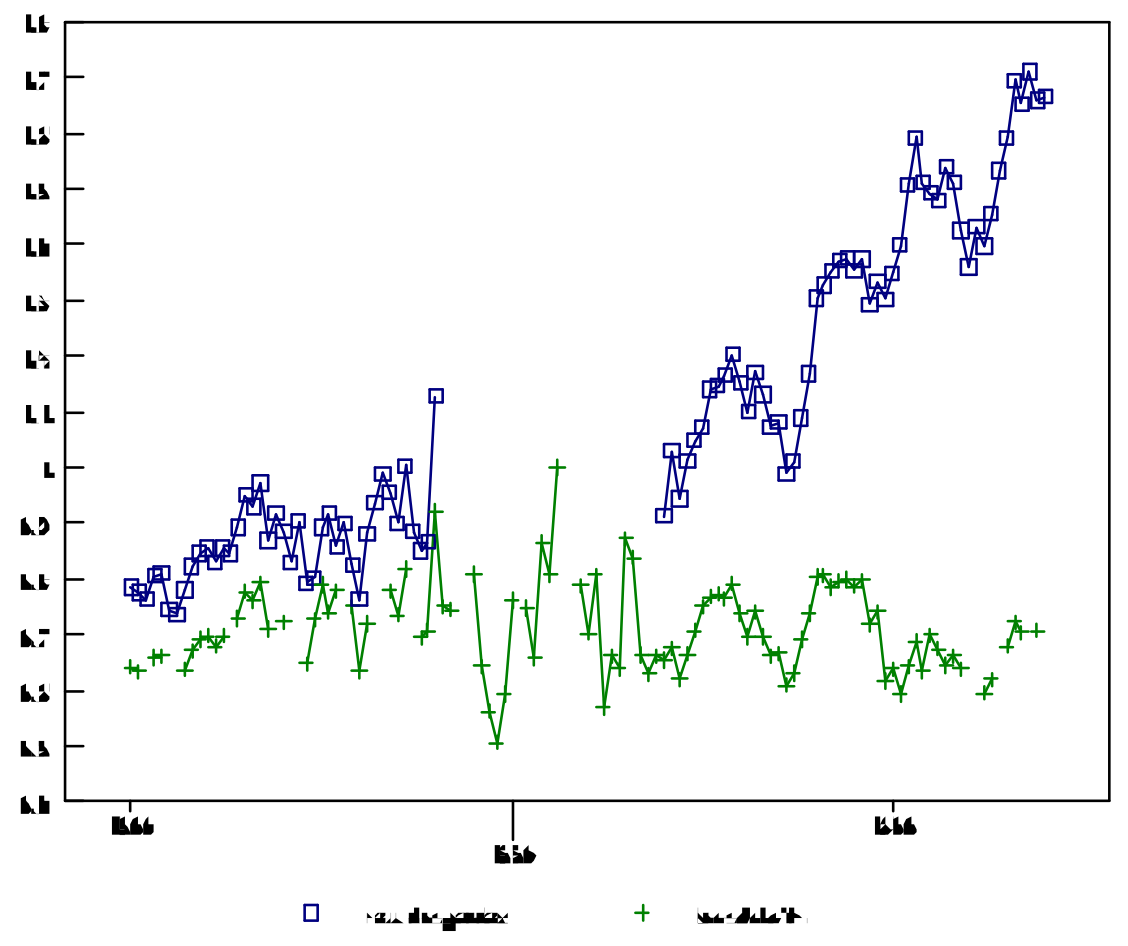


Figure 5

The Supply and Demand for Labour

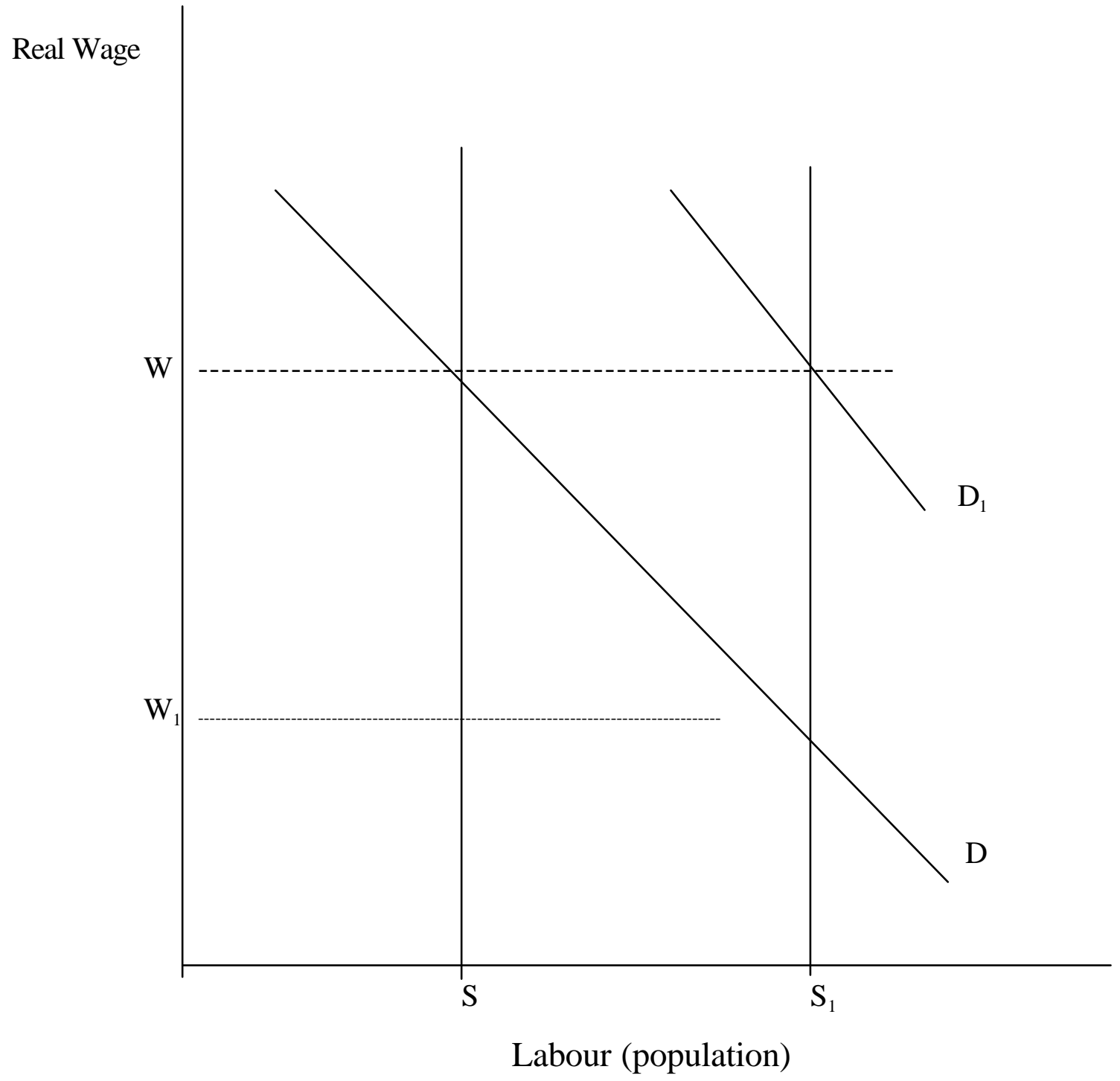


Figure 6

Simulated Urbanization Rate, 1300-1800

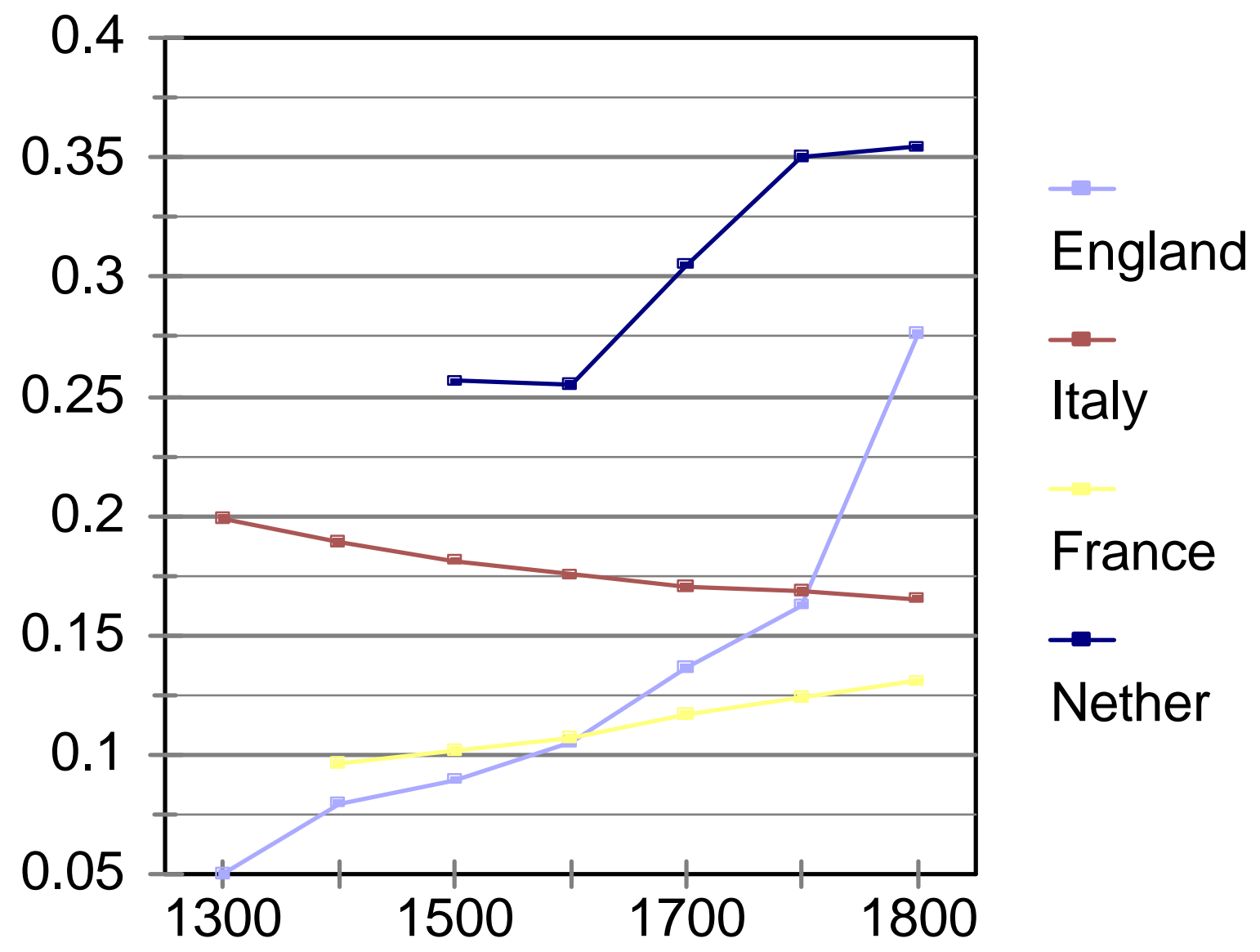


Figure 7

Simulated Agricultural TFP, 1300-1800

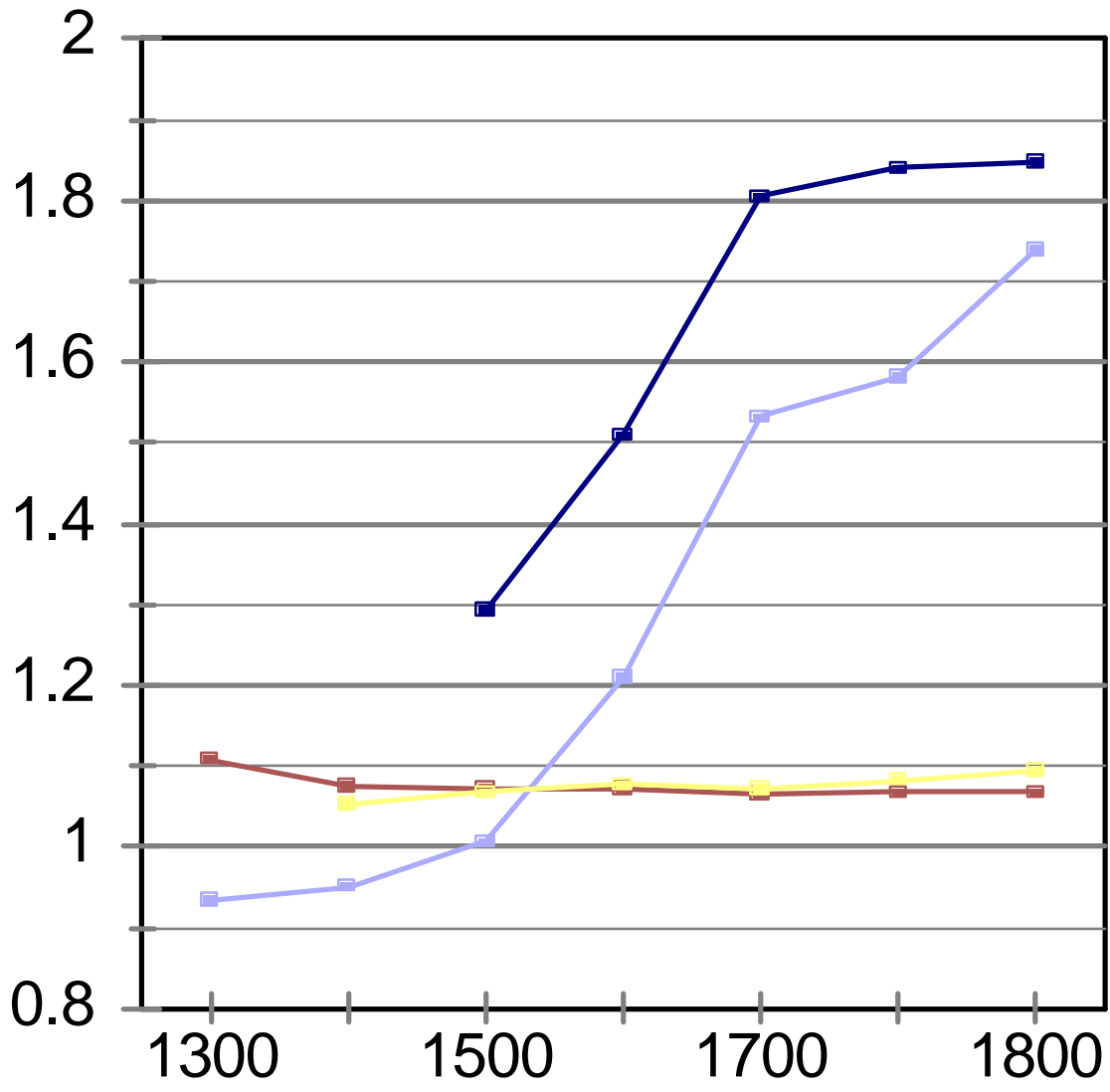

England

Italy

France

Nether 
Figure 8

Simulated Real Wage, 1300-1800

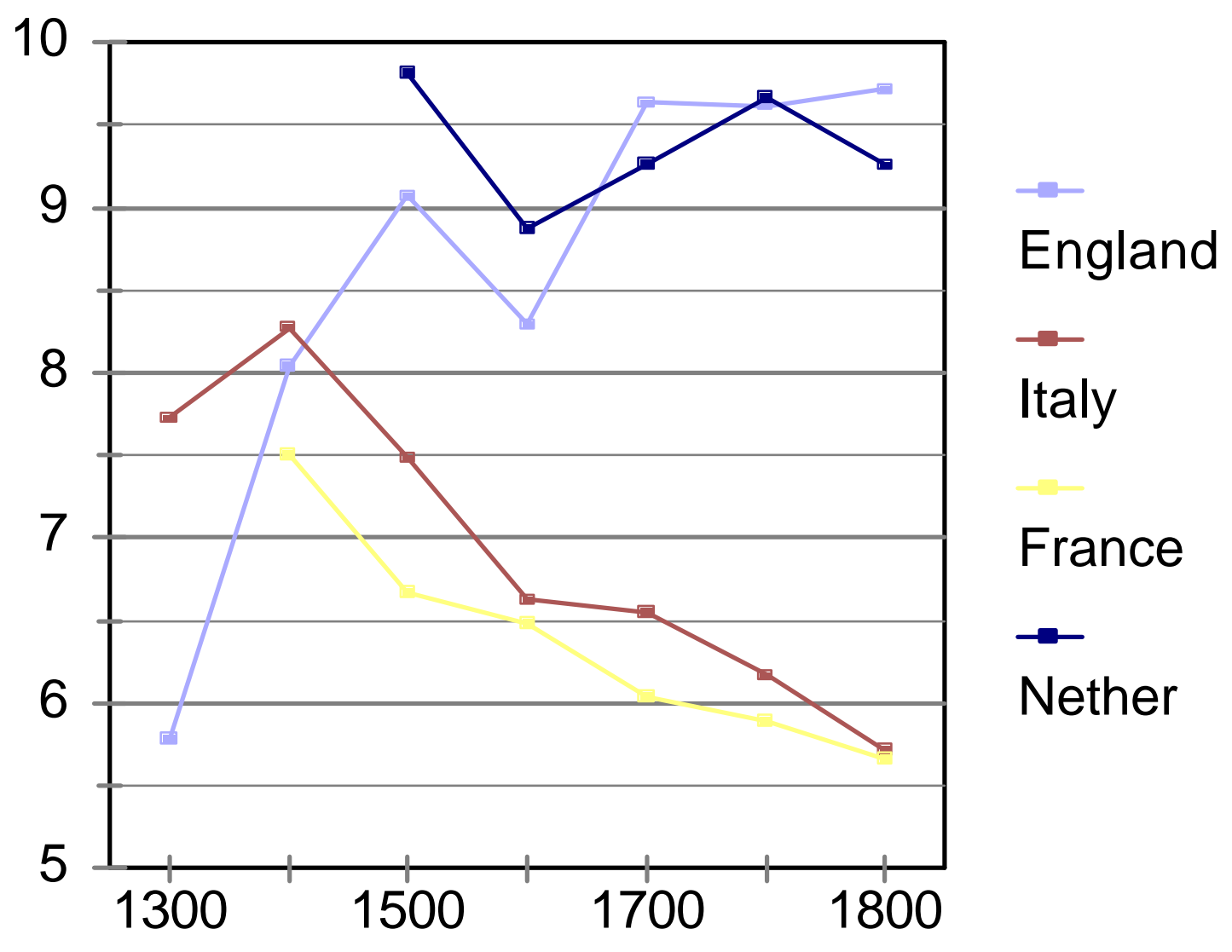


Figure 9

Simulated Urbanization Rate, 1300-1800

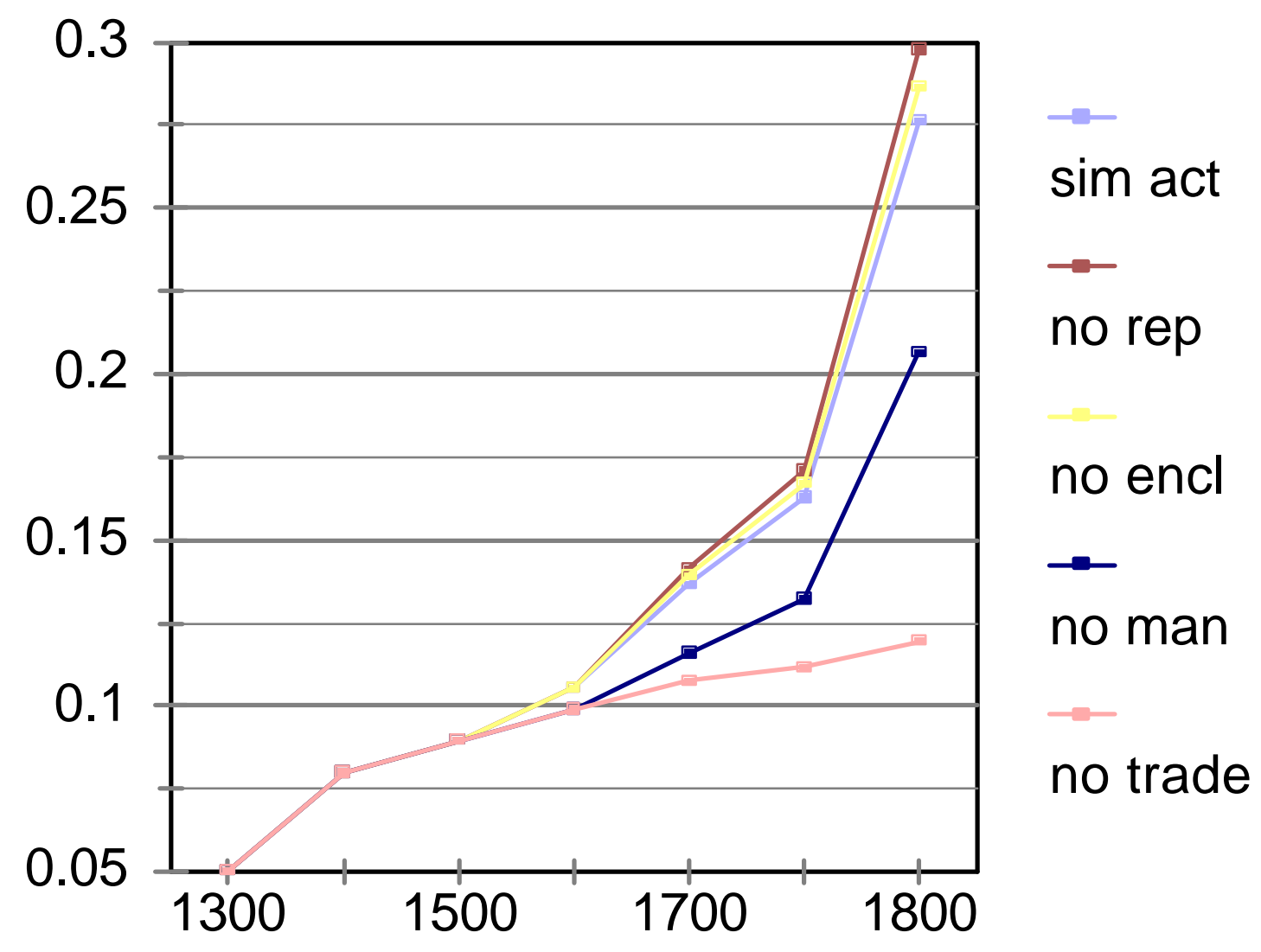


Figure 10

Simulated Agricultural TFP, 1300-1800

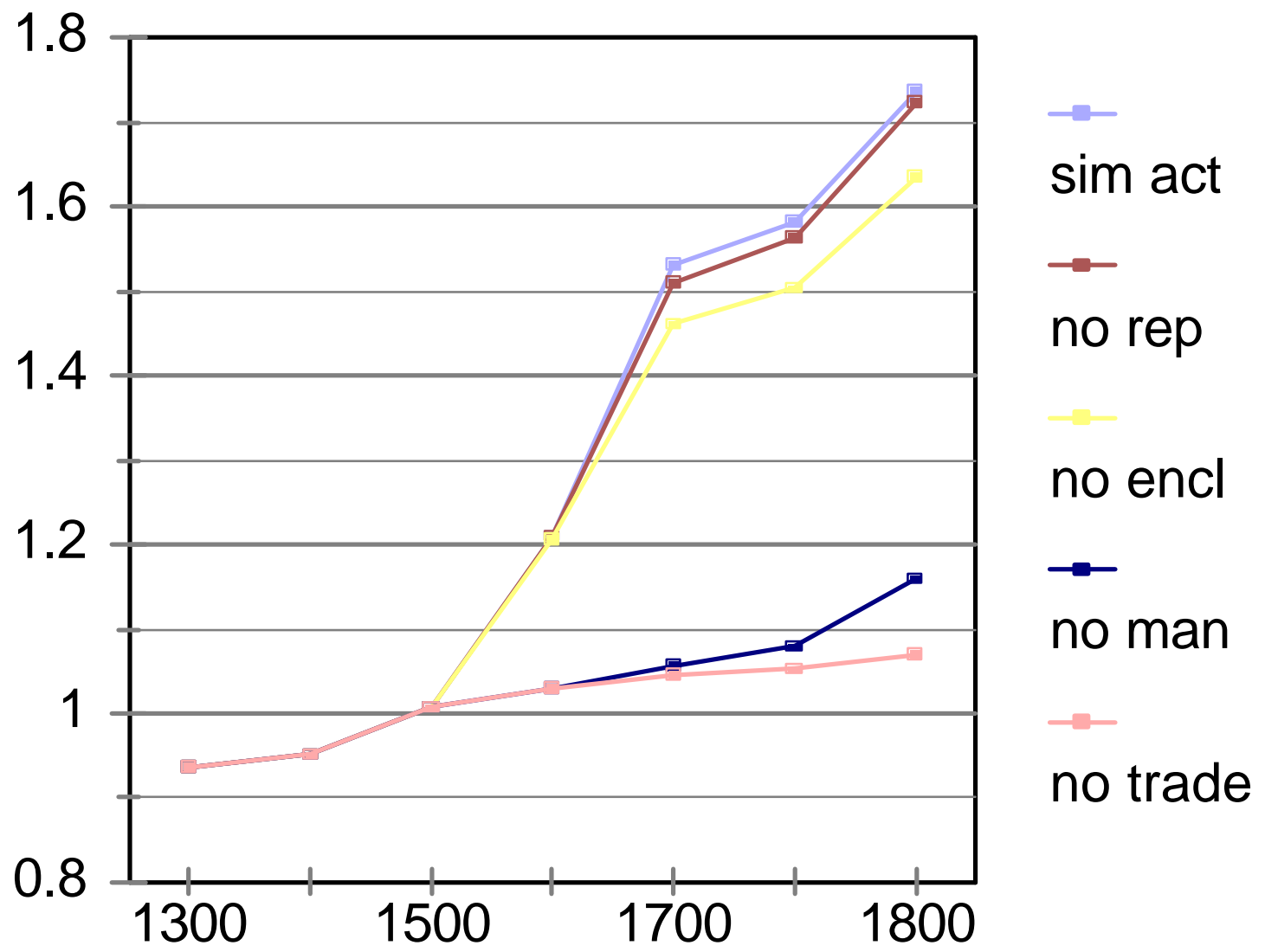


Figure 11

Simulated Real Wage, 1300-1800

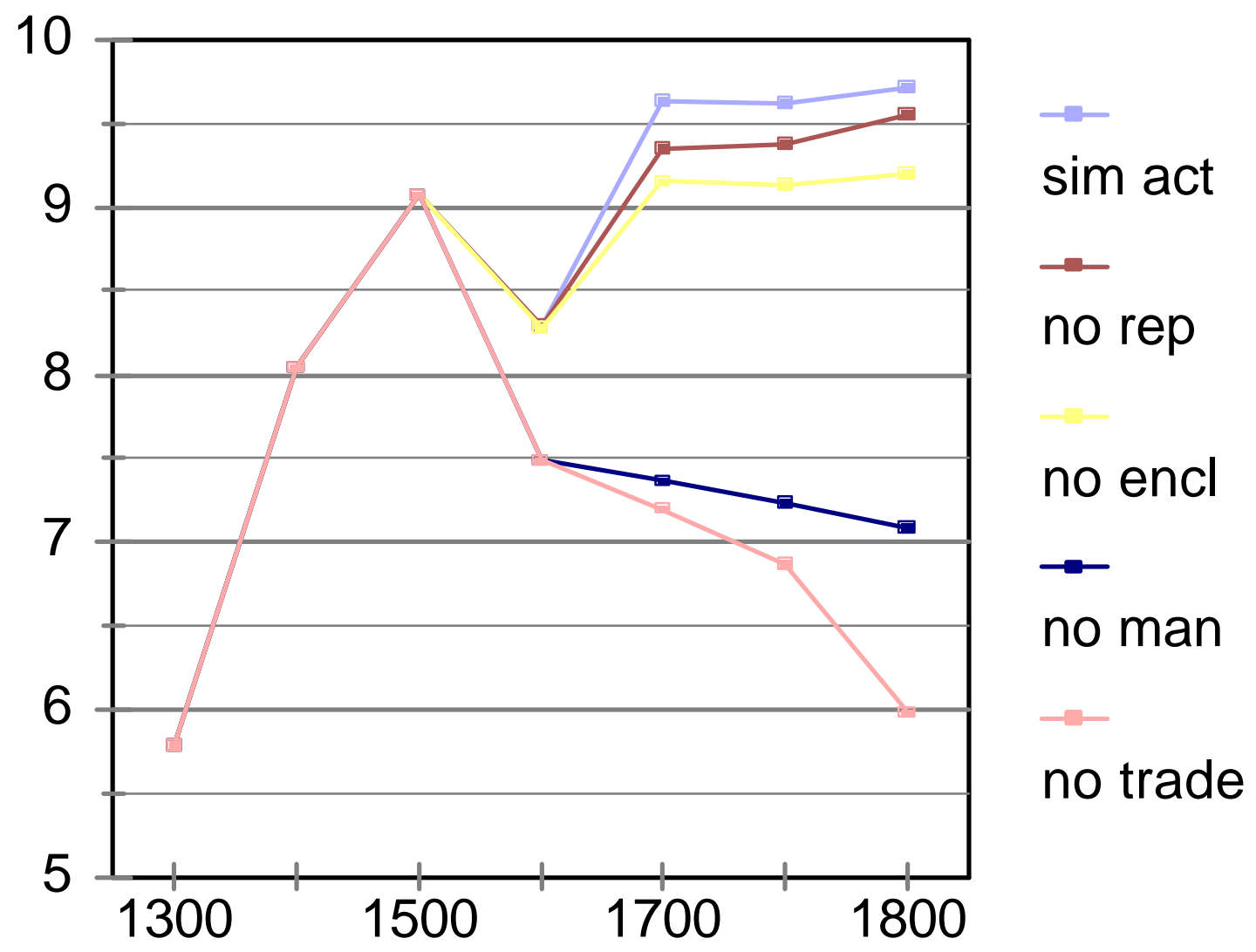


Figure 12

Simulated Population, 1300-1800

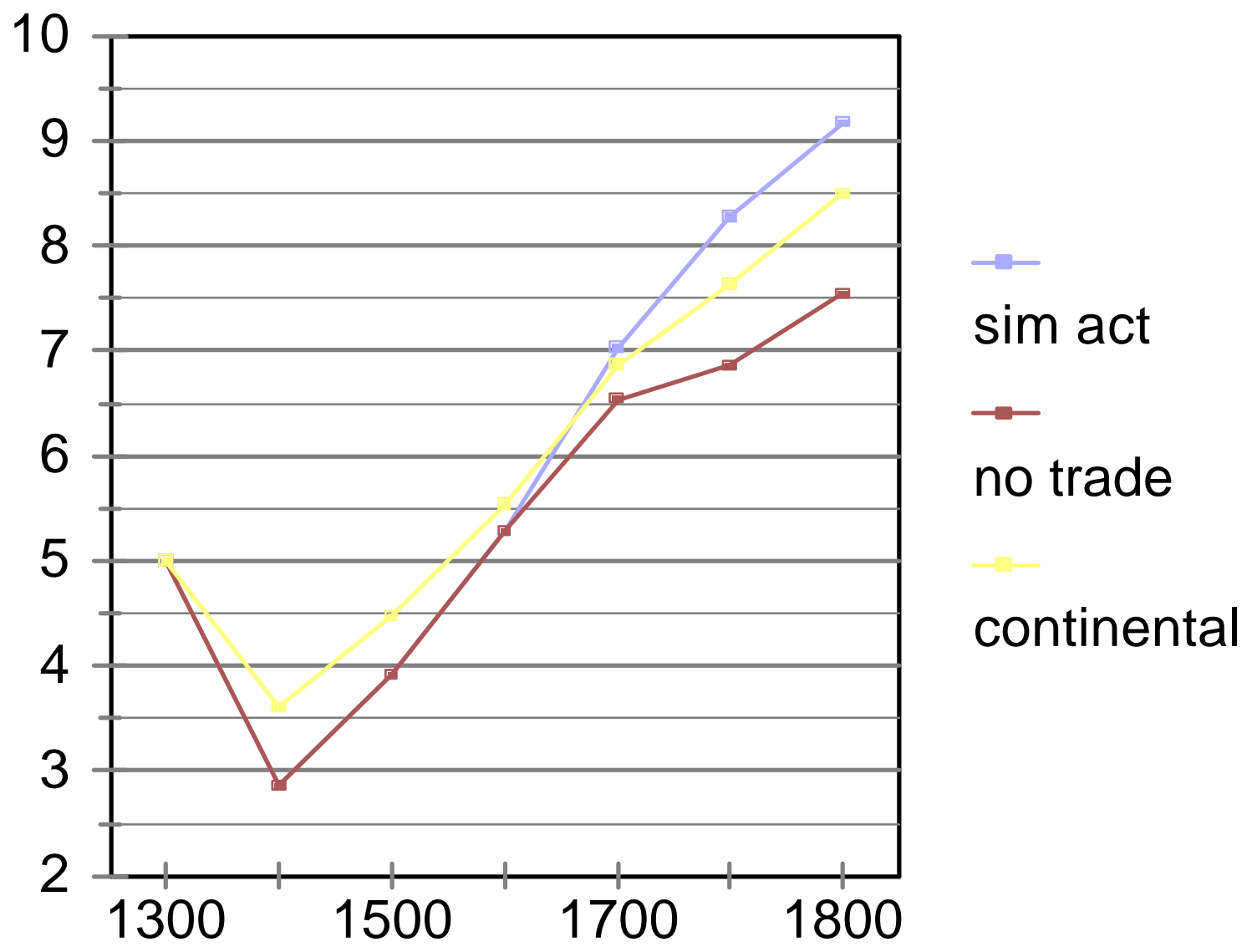


Appendix I

Agricultural Total Factor Productivity

Agricultural TFP was estimated as follows. First, the logarithm of output per agricultural worker was regressed on the logarithm of the land-labour ratio for those 41 observations in which productivity was manifestly low. Excluded were all observations for Belgium, the Netherlands, and from England in 1700,1750 , and 1800. The estimated regression was:

$$
\operatorname{lnl} \mathrm{p}=\frac{-3.19+.29 * \ln \operatorname{lag} l}{(-7.82)(5.75)}
$$

In this equation lnlp is the logarithm of output divided by the agricultural population and lntagl is agricultural land divided by the agricultural population. The t-ratios are shown in parentheses. $R^{2}$ was .45 . This equation was used to predict output per worker for all observations in the sample including those excluded in the estimation. The index of agricultural TFP is ratio actual output per worker to output per worker predicted by the regression equation.

Ideally, capital per worker should also be included as an independent variable in this regression, but data to measure it are not available for all of the countries and time periods. However, when the productivity indices derived here can be compared to total factor productivity indices based on fuller information (e.g. for England as in Allen 1999), there are not major discrepancies. That is the warrant for referring to these productivity indices as TFP. 


\section{$\underline{\text { References }}$}

Abel, Wilhelm (1980). Agricultural Fluctuations in Europe from the Thirteenth to the Twentieth Centuries, trans by Olive Ordish, London, Methuen.

Acemoglu, Daren, Johnson, Simon, and Robinson, James (2002). 'The Rise of Europe: Atlantic Trade, Institutional Change and Economic Growth.'

Allen, Robert C. (1992). Enclosure and the Yeoman, Oxford, Clarendon Press.

Allen, Robert C. (1994). 'Agriculture During the Industrial Revolution,' in Roderick Floud and D.N. McCloskey, The Economic History of Britain since 1700: Vol. I: 1700-1860, Cambridge, Cambridge University Press, second edition, pp. 96-122.

Allen, Robert C. (1999). 'Tracking the Agricultural Revolution,' Economic History Review, $2^{\text {nd }}$ series, Vol. 52, pp. 209-35.

Allen, Robert C. (2000). 'Economic Structure and Agricultural Productivity in Europe, 1300-1800,' European Review of Economic History, Vol. 3, pp. 1-25.

Allen, Robert C. (2001). 'The Great Divergence in European Wages and Prices from the Middle Ages to the First World War,'

Explorations in Economic History, Vol. 38, October, 2001, pp 411447 .

Allen, Robert C. and O'Grada, Cormac (1988). 'On the Road Again with Arthur Young: English, Irish, and French Agriculture during the Industrial Revolution,' Journal of Economic History, Vol. 38, pp. 93-116.

Arrighi, Giovanni (1994). The Long Twentieth Century: Money, Power, and the Origins of Our Time, London, Verso.

Aston, T.H.and Philpin, C.H.E, eds. (1985). The Brenner Debate, Cambridge, Cambrdige University Press.

Bairoch, Paul (1988). La Population des villes européennes, 8001850: banque de données et analyse sommaire des résultats, Geneva, Droz. 
Barro, Robert J.(1997). Determinants of Economic Growth: A CrossCountry Empirical Study, Cambridge, MA, The MIT Press.

Blaut, J.M. (1993). The Colonizer's Model of the World, New York, The Guildford Press.

Bonney, Richard (1999). The Rise of the Fiscal state in Europe, c. 1200-1815, Oxford, Oxford University Press.

Brenner, Robert (1976). 'Agrarian Class Structure and Economic Development in Pre-Industrial Europe,' in T.H. Aston and C.H.E. Philpin, eds., The Brenner Debate, Cambridge, Cambrdige University Press, 1985, pp. 10-63.

Campbell, B.M.S. (2002). English Seigniorial Agriculture, 12501450, Cambridge, Cambridge University Press.

Chalklin, Christopher (2001). The Rise of the English Town, 16501850, Cambridge, Cambridge University Press.

Chartier, Roger (1987). Lectures et Lecturers dans la France de l'ancien regime, Paris, Seuil.

Cipolla, Carlo M. (1969). Literacy and Development in the West, Harmondsworth, Penguin.

Clark, Greg (1996). 'The Political Foundations of Modern Economic Growth: England, 1540-1800,' Journal of Interdisciplinary History, Vol. 26, pp. 563-88.

Clark, Greg (1998). 'Commons Sense: Common Property Rights, Efficiency, and Institutional Change,' Journal of Economic History, Vol. 48, pp. 73-102.

Coleman, D.C. (1983). 'Protoindustrialization: A Concept too Many,' Economic History Review, $2^{\text {nd }}$ series, Vol. 36, pp. 435-448.

Crafts, N.F.R. and Harley, C.K. (1992). 'Output Growth and the British Industrial Revolution: A Restatement of the Crafts-Harley View,' Economic History Review, $2^{\text {nd }}$ series, Vol. 45, pp. 703-30.

Crafts, N.F.R. and Harley, C.K. (2000). 'Simulating the Two Views of the Industrial Revolution,' Journal of Economic History, Vol. 60 , pp. 819-841. 
Crafts, N.F.R. and Harley, C.K. (2002). 'Precocious British Industrialization: A General Equilibrium Perspective,', London School of Economics, Working Papers in Economic History, No. $67 / 02$.

Cressy, David (1980). Literacy and the Social Order: Reading and Writing in Tudor and stuart England, Cambridge, Cambridge University Press.

Cressy, David (1981). 'Levels of Illiteracy in England, 15301730' in Harvey J. Graff, ed., Literacy and Social Development in the West: A Reader, Cambridge, Cambridge University Press.

Crouzet, F. (1985). Britain Ascendant: Comparative Studies in Franco-British Economic History, trans. By Martin Thom, Cambridge, Cambridge University Press.

Darity, William (1992). 'A Model of 'Original Sin': Rise of the West and Lag of the Rest, American Economic Review, Vol. 82, No. 2 , pp. $162-7$.

Davis, Ralph (1954). 'English Foreign Trade, 1660-1700,' Economic History Review, $2^{\text {nd }}$ series, Vol. 7, pp. 150-166.

Deane, Phyllis, and Cole, W.A. (1969). British Economic Growth, 1688-1959, Cambridge, Cambridge University Press, $2^{\text {nd }}$ edition.

Denison, Edward F. (1962). The Sources of Economic Growth in the United States and the Alternatives Before Us, New York, Committee for Economic Development, Supplementary Paper No. 13.

De Long, J. Bradford and Schleifer, Andrei (1993). 'Princes and Merchants: European City Growth before the Industrial Revolution,' Journal of Law and Economics, Vol. 36, pp. 671-702.

De Vries, Jan (1974). The Dutch Rural Economy in the Golden Age, 1500-1700, New Haven, Yale University Press.

De Vries, Jan (1984). European Urbanization, 1500-1800, Cambridge, MA, Harvard University Press.

De Vries, Jan, and van der Woude, Ad (1997). The First Modern Economy: Success, Failure and Perseverance of the Dutch Economy, 1500-1815, Cambridge, Cambridge University Press. 
Deane, Phyllis (1957). 'The Output of the British Woollen Industry in the Eighteenth Century,' Journal of Economic History, Vol. 17, pp. 207-23.

Drelichman, M. (2002). The Curse of Moctezuma: American Silver and the Dutch Disease, 1501-1650,' Northwestern University.

Ellis, Joyce (2001). The Georgian Town, 1680-1840, Basingstoke, Palgrave.

Engerman, S.L. (1972). The Slave Trade and British Capital Formation in the Eighteenth Century: A Comment on the Williams Thesis,' Business History Review,

Engerman, S.L. (1998). 'British Imperialism in a Mercantilist Age, 1492-1849,' Revista de Historia Economica, Vol. I, pp. 195225 .

Epstein, S.R. (2000) Freedom and Growth: The Rise of States and Markets in Europe, 1300-1750, London, Routledge.

Findlay, Ronald (1990). 'The 'Triangular Trade' and the Atlantic Economy of the Eighteenth Century: A Simple General-Equilibrium Model,' Essays in International Einance, No. 177, Princeton, Princeton University.

Fisher, John (1985). Commercial Relations Between Spain and Spanish America in the Era of Free Trade, 1778-1796, Centre for Latin American Studies, University of Liberpool, Monograph Series, 13 .

Fisher, John (1997). The Economic Aspects of Spanish Imperialism in America, Liverpool, Liverpool University Press.

Furet, Francois and Ozouf, Jacques (1977). Lire et ecrire: alphabetisation des Francaises de Calvin a Jules Ferry, Paris, Editions de Minuit.

Fraga, Antonio Vinao (1990). 'The History of Literacy in Spain: Evolution, Traits and Questions,' History of Education Quarterly, Vol. 30., pp. 573-99.

Frank, A.G. (1978). World Accumulation, 1492-1789, London, MacMillan Press. 
Frank, A.G. (1998). Reorient: Global Economy in the Asian Age, Berkeley, University of California Press.

Francois, Etienne (1989). 'Lire et Ecrire en France et en Allemagne au temps de la Revolution,' in La Revolution, la France et l'Allegmagne: deux modeles opposes de changement social?, ed. By Helmut Berding, Etienne Francois and Hand-Peter Ullmann, Paris, Maison des Sciences de l'Homme.

Garcia Fuentes, Lutgardo (1980). El comercio espanol con America, 1650-1700, Seville, Escuela de Estudios Hispano-Americanos, CSIS.

Gelabert, J.E. (1987). 'Niveaux d'alphabetisation en Galice (1635-1900)' in De l'alphabetisation aux circuits du livre en Espagne xvie-xixe siecles, Paris, CNRS.

Gilboy, Elizabeth W. (1934). Wages in Eighteenth Century England, Cambridge, Harvard University Press.

Goldin, Claudia, and Katz, Lawrence (1998). 'The Origins of Technology-Skill Complementarity,' Quarterly Journal of Economics, Vol. 113, pp. 693-732.

Graff, Harvey J. (1987). The Legacies of Literacy: Continuities and Contradictions in Western culture and Society, Bloomington, Indian University Press.

Grantham, George (1978). The Diffusion of the New Husbandry in Northern France,' Journal of Economic History, Vol. 38, pp. $311-$ 37 .

Grantham, George (1989). 'Agricultural Supply during the Industrial Revolution: French Evidence and European Implications,' Journal of Economic History, Vol. 49, pp. 43-72.

Grendler Paul F. (1989). Schooling in Renaissance Italy: Literacy and Learning, 1300-1600, Baltimore, Johns Hopkins University Press.

Hajnal, J. (1965). 'European Marriage Patterns in Perspective,' in D. Glass and D. Eversley, eds., Population in History: Essays in Historical Demography, Chicago, Aldine, pp.101-143.

Hamilton, Earl J. (1934). American Treasure and the Price Revolution in Spain, 1501-1650, New York, Octagon Books, reissued 1970 . 
Hamilton, Earl J. (1936). Money, Prices, and Wages in Valencia, Aragon, and Navarre, 1351-1500, Philadelphia, Porcupine Press, reissued 1975 .

Hamilton, Earl J. (1947). War and Prices in Spain, 1650-1800, New York, Russell \& Russell, reissued 1969.

Hardin, G.J. (1998). Managing the Commons, Bloomington, Indiana University Press, $2^{\text {nd }}$ edition.

Haudere, Phillippe (1989). La compagnie francaise des indes au xviiie siècle (1719-1795), Paris, Libraire de l'Inde Éditeur

Hayami, Yujiro, and Otsuka, Keijiro (1993). The Economics of Contract Choice: An Agrarian Perspective, Oxford, Clarendon Press.

Hoffman, Philip T. (1996). Growth in a Traditional Society: The French Countryside, 1450-1815, Princeton, Princeton University Press.

Hoffman, Philip T. and Norberg, Kathryn (1994). Fiscal Crises, Liberty, and Representative Government, 1450-1789, Stanford, Stanford University Press.

Hoffman, Philip T., Postel-Vinay, Gilles, and Rosenthal, JeanLaurent (2000). Pricless Markets: The Political Economy of Credit in Paris, 1660-1870, Chicago, University of Chicago Press.

Holderness, B.A. (1997). The Reception and Distribution of the New Draperies in England,' in N.B. Harte, ed., The New Draperies in the Low Countries and England, 1300-1800, Oxford, Oxford University Press, pp. 217-243.

Houston, Robert Allan (1988). Literacy in Early Modern Europe: Culture and Education, 1500-1800, London, Longman.

Jacob, Margaret C. (1997). Scientific Culture and the Making of the Industrial West, New York, Oxford University Press.

Jones, C.I. (1998). Introduction of Economic Growth, New York, W.W. Norton \& Company.

Jones, E.L. (1981). The European Miracle, Cambridge, Cambridge University Press. 
Kuijpers, Erika (1997). 'Lezen en schrijven: Onderzoek naar het Alfabetiseringsniveau inb zeventiendeeeuws Amsterdam' Tijdschrift voor Sociale Geschiedenis, Vol. 23, pp. 490-522.

Larguie, Claude (1987) 'L'Alphabetisation des Madrilenos dans la Seconde Moitie du xviieme siecle: stagnation our evolution?' in De l'alphabetisation aux circuits du livre en Espagne, xvie-xixe siecles Paris, CNRS.

Le Roy Ladurie (1974). The Peasants of Languedoc, trans by John Day, Urbana, University of Illinois Press.

Levasseur, E. (1911). Histoire de la commerce de France, Paris, Arthur Rousseau, Éditeur.

Lucassen, Jan (1987). Migrant Labour in Europe, 1600-1900, trans. By Donald A. Bloch, London, Croom Helm.

Maddison, Angus (1995). Monitoring the World Economy, 1820-1992, Paris, OECD.

Martin, Luc (1997). 'The Rise of the New Draperies in Norwich,' in N.B. Harte, ed., The New Draperies in the Low Countries and England, 1300-1800, Oxford, Oxford University Press, pp. 245-74.

Mathias, P. And O'Brien, P.K. (1976). 'Taxation in England and France, 1715-1810,' Journal of European Economic History, Vol. 5, pp. 601-50.

Mathias, P. And O'Brien, P.K. (1978). 'The Incidence of Taxes and the Burden of Proof' Journal of European Economic History, Vol. 7, pp. 211-13.

McEvedy, C., and Jones, R. (1978). Atlas of World Population History, London, Penguin Books.

Mendels, F.F. (1972). 'Proto-Industrialization: The First Phase of the Industrialization Process,' Journal of Economic History, Vol. 32, pp. 241-61.

Mitch, David (1993). The Role of Human Capital in the First Industrial Revolution, in Joel Mokyr, ed., The British Industrial Revolution: An Economic Perspective, Bouler, Westview Press, pp. 267-307. 
Mokyr, Joel (2002). The Gifts of Athena: Historical Origins of the knowledge Economy, Princeton, Princeton University Press.

Morineau, Michel (1985). Incroyable gazettes et fabuleux métaux, Paris, Éditions de la Maison des Sciences de l'Homme.

Monro, John H. (1997). 'The Origin of the English 'New Draperies': The Resurrection of an Old Flemish Industry, 12701570,' in N.B. Harte, ed., The New Draperies in the Low Countries and England, 1300-1800, Oxford, Oxford University Press, pp. 35127 .

Morgan, Kenneth (2001). Slavery, Atlantic Trade and the British Economy, New York, Cambridge University Press.

Nalle Sara T. (1989). 'Literacy and Culture in Early Modern Castille,' Past and Present, 125, pp. 65-96.

North, D.C., and Thomas, R.P. (1973). The Rise of the Western World, Cambridge, Cambridge University Press.

North, D.C. and Weingast, B.R. (1989). 'Constitutions and Commitment: Evolution of Institutions Goverining Public Choice in Seventeenth Century England,' Journal of Economic History, Vol. 49 , pp. $803-832$.

Nugent, J.B., and Sanchez, N. (1989). 'The Efficiency of the Mesta: A Parable,' Explorations in Economic History, Vol. 26, pp. $261-84$.

O'Brien, Patrick K. (1982). 'European Economic Development: The Contribution of the Periphery,' Economic History Review, $2^{\text {nd }}$ series, Vol. 35, pp. 1-18.

O'Brien, Patrick K. (1996). 'Path Dependency, or Why Britain Became an Industrialized and Urbanized Economy Long Before France,' Economic History Review, $2^{\text {nd }}$ series, Vol. 49, pp. 21349 .

O'Brien, Patrick K. (1999). 'Imperialism and the Rise and Decline of the British Economy, 1688-1989,' New Left Review, Number 238, pp. $48-80$.

O'Brien, Patrick K., and Engerman, Stanley L. (1991). 'Exports and the Growth of the British Economy from the glorious

Revolution to the Peace of Amiens,' in Barbara L. Solow, eds., 
Slavery and the Rise of the Atlantic System, Cambridge, Cambridge University Press, pp. 177-209.

O'Brien, Patrick K. and Keyder, C. (1978). Economic Growth in Britain and France, 1780-1914: Two Paths to the Twentieth

Century, London, George Allen and Unwin.

O'Brien, Patrick, and Prados de la Escosura, Leandro (1998). 'The Costs and Benefits of European Imperialism from the Conquest of Cueta, 1451, to the Treaty of Lusaka, 1974,' in Debates and Controversies in Economic History, ed. By C-E. Nunez, Madrid, pp. $9-69$.

Park, Geoffrey (1980). 'An Education Revolution? The Growth of Literacy and School in Early Modern Europe,' Tijdschrift voor Geschiendenis, Vol. 93, pp. 210-22.

Phelps Brown, E.H., and Hopkins, Sheila V. (1955). 'Seven Centuries of Building Wages,' Economica NS, Vol. 22, pp. 195-206.

Pomeranz, Kenneth (2000). The Great Divergence: China, Europe, and the Making of the Modern World, Princeton, Princeton University Press.

Postan, M.M. (1950). Some Agrarian Evidence of Declining Population in the Later Middle Ages,' Economic History Review, $2^{\text {nd }}$ series, Vol. 2, pp. 221-46.

Postan, M.M. (1975). The Medieval Economy and Society, Harmondsworth, Penguin Books.

Prados de la Escosura, Leandro (2000). 'International Comparisons of Real Product, 1820-1990: An Alternative Data Set,' Explorations in Economic History, Vol. 37, pp. 1-41.

Quinn, Stephen (2001). 'The Glorious Revolution's Effect on English Private Finance: A Microhistory, 1680-1705,' JEH Vol. 61, pp. 593-615.

Rapp, R. (1975). 'The Unmaking of the Mediterranean Trade Hegemony: International Trade Rivalry and the Commercial Revolution,' Journal of Economic History, Vol. 35, pp. 499-525.

Reis, Jaime (2000). 'Human Capital, Immaterial Goods, and the Standard of Living in Pre-Industrial Europe', Arild, Sweden, 
Conference on New Evidence of the Standard of Living in Preindustrial Europe and Asia, revised.

Ringrose, David R. (1983). Madrid and the Spanish economy, 15601850, Berkeley, University of California Press.

Rosenthal, J.-L. (1990). The Development of Irrigation in Provence,' Journal of Economic History, pp. 615-38

Sandberg, L.G. (1979). 'The Case of the Impoverished Sophisticate: Human Capital and Swedish Economic Growth Before World War I,' Journal of Economic History, Vol. 39, pp. 225-41.

Simpson, James (1995). Spanish Agriculture: The Long Siesta, 1765-1965, Cambridge, Cambridge University Press.

Stamp, Dudley (1965). Land Use Statistics of the Countries of Europe, The World Land Use Survey, Occasional Papers \#3, Bude, Cornwall, Geographical Publications Ltd.

Sweet, Rosemary (1999). The English Town, 1680-1840, Harlow, Longman .

Thomas, R.P., and Bean, R.N. (1974). 'The Fishers of Men: The Profits of the Slave Trade,' Journal of Economic History Vol. 34, pp. 885-914.

Van Zanden, Jan Luiten (1993). The Rise and Decline of Holland's Economy: Merchant Capitalism and the Labour Market, Manchester, Manchester University Press.

Van Zanden, Jan Luiten (2002). 'The 'Revolt of the Early Modernists' and the 'First Modern Economy:' An Assessment, Economic History Review $2^{\text {nd }}$ series, Vol. 55, pp. Xx.

Villiers, Patrick (1991). The Slave and Colonial Trade in France just Before the Revolution,' in Barbara Solow, ed., Slavery and the Rise of the Atlantic System, Cambridge, Cambridge University Press, pp. 210-36.

Wallerstein, I.M. (1974-91). The Modern World System, 3 volumes, New York, Academic Press.

Weir, D. (1984). 'Life Under Pressure: France and England, 16701870,' Journal of Economic History, Vol. 44, pp. 27-47. 
Williams, Eric (1944). Capitalism and Slavery, New York, Capricorn Books.

Williamson, J.G. (1990). The Impact of the Corn Laws Just Prior to Repeal,' Explorations in Economic History, Vol. 27, pp. $123-56$.

Woodward, Donald (1995). Men at Work: Labourers and Building Craftsmen in the Towns of Northern England, 1450-1750, Cambridge, Cambridge University Press.

Wordie, J.R. (1983). 'The Chronology of English Enclosure, 15001914,' Economic History Review, $2^{\text {nd }}$ series, Vol. 36, pp. 483-505.

Wrigley, E.A. (1967). 'A Simple Model of London's Importance in Changing English Society and Economy, 1650-1750,' Past and Present, Vol. 37, pp. 44-70.

Wrigley, E.A. (1985). 'Urban Growth and Agricultural Change: England and the Continent in the Early Modern Period,' Journal of Interdisciplinary History, Vol. 15, pp. 683-728.

Wrigley, E.A. (1988). Continuity, Chance and Change, Cambridge, Cambridge University Press.

Wrigley, E.A. and Schofield, R.S. (1981). The Population History of England, 1541-1871, London, Edward Arnold.

Wyczanski, Andrzej (1974). 'Alphabetisation et structure sociale en Pologne au xvie siecle,' Annales: Economies, Societes, Civilisations, vol. 29, pp. 705-13. 